University of Wollongong

Research Online

Australian Institute for Innovative Materials -

Papers

Australian Institute for Innovative Materials

$1-1-2020$

Development of $\mathrm{CeO} 2$ nanodot encrusted $\mathrm{TiO} 2$ nanoparticles with reduced photocatalytic activity and increased biocompatibility towards a human keratinocyte cell line

\author{
Alexander Morlando \\ University of Wollongong, am700@uowmail.edu.au \\ Marcela Chaki Borras \\ University of Wollongong, mlcb986@uowmail.edu.au \\ Yaser Rehman \\ University of Wollongong, yr997@uowmail.edu.au \\ Shahnaz Bakand \\ University of Wollongong, sbakand@uow.edu.au \\ Philip J. Barker \\ University of Wollongong, pbarker@uow.edu.au
}

See next page for additional authors

Follow this and additional works at: https://ro.uow.edu.au/aiimpapers

Part of the Engineering Commons, and the Physical Sciences and Mathematics Commons

Research Online is the open access institutional repository for the University of Wollongong. For further information contact the UOW Library: research-pubs@uow.edu.au 


\title{
Development of $\mathrm{CeO} 2$ nanodot encrusted $\mathrm{TiO} 2$ nanoparticles with reduced photocatalytic activity and increased biocompatibility towards a human keratinocyte cell line
}

\author{
Abstract \\ The cytotoxic and genotoxic effects of titanium dioxide (TiO2) nanoparticles when exposed to ultraviolet \\ (UV) radiation, particularly wavelengths between $320-400 \mathrm{~nm}$, has raised concern over their safe use in \\ health and cosmetic related products such as sunscreens. Cerium dioxide (CeO2) nanoparticles have \\ been demonstrated to display biocompatible properties and antioxidant activity due to redox cycling of \\ the $\mathrm{Ce} 3+/ \mathrm{Ce} 4+$ oxidation states. In this work, $\mathrm{CeO} 2 / \mathrm{TiO} 2$ nanocomposites were prepared through a \\ standard precipitation method at atomic concentrations (at\%) of Ce relative to Ti of $2.5,5$ and 10 at\%, \\ with the aim of reducing the photocatalytic activity of the core $\mathrm{TiO} 2$ nanoparticles and improve \\ biocompatibility. The UV absorptive properties of the nanocomposite samples revealed excellent \\ absorbance across the UV region as compared to pristine $\mathrm{TiO} 2$ and $\mathrm{CeO} 2$. Furthermore, a drastic \\ reduction in the photocatalysed decomposition of crystal violet, when in the presence of the \\ nanocomposite samples, under both UV and solar simulated light was observed compared to the highly \\ photoactive pristine $\mathrm{TiO} 2$. An optimal $\mathrm{CeO} 2$ nanodot loading, displaying both high UV attenuation and low \\ photocatalytic performance was determined at 5 at $\%$ and further in vitro biological testing revealed \\ minimal impact on the cell viability of the human keratinocyte cell line (HaCaT) over a $24 \mathrm{~h}$ period with \\ and without prior exposure to UV irradiation. In contrast, pristine TiO2 nanoparticles induced toxicity to \\ $\mathrm{HaCaT}$ cells with prior UV exposure before incubation, particularly at a dosage of $100 \mathrm{mg}$ L-1. Our findings \\ demonstrate the effectiveness of $\mathrm{CeO} 2$ nanodots in improving biocompatibility and its potential as a \\ coating material for active inorganic UV filters. \\ Disciplines \\ Engineering | Physical Sciences and Mathematics

\section{Publication Details} \\ Morlando, A., Chaki Borras, M., Rehman, Y., Bakand, S., Barker, P., Sluyter, R. \& Konstantinov, K. (2020). \\ Development of $\mathrm{CeO} 2$ nanodot encrusted $\mathrm{TiO} 2$ nanoparticles with reduced photocatalytic activity and \\ increased biocompatibility towards a human keratinocyte cell line. Journal of Materials Chemistry B, 8 \\ (18), 4016-4028.
}

\section{Authors}

Alexander Morlando, Marcela Chaki Borras, Yaser Rehman, Shahnaz Bakand, Philip J. Barker, Ronald Sluyter, and Konstantin K. Konstantinov 
Development of $\mathrm{CeO}_{2}$ nanodot encrusted $\mathrm{TiO}_{2}$ nanoparticles with reduced photocatalytic activity and increased biocompatibility towards the human keratinocyte cell line

Alexander Morlando ${ }^{\text {a }}$,Marcela Chaki Borrás ${ }^{\mathrm{a}, \mathrm{b}, \mathrm{c}}$, Yaser Rehman ${ }^{\mathrm{a}}$, Shahnaz Bakand ${ }^{\text {c,d }}$, Philip J. Barker $^{\mathrm{b}}$, Ronald Sluyter ${ }^{\mathrm{b}, \mathrm{c}}$, Konstantin Konstantinov ${ }^{\mathrm{a}}$

${ }^{a}$ Institute for Superconducting and Electronic Materials, Australian Institute for Innovative Materials, University of Wollongong, NSW, 2500, Australia

${ }^{\mathrm{b}}$ Molecular Horizons and School of Chemistry and Molecular Bioscience, University of Wollongong, Wollongong, NSW, 2522 Australia

${ }^{\mathrm{c}}$ Illawarra Health and Medical Research Institute, Wollongong, NSW, 2522, Australia

${ }^{\mathrm{d}}$ School of Health and Society, University of Wollongong, NSW, 2522, Australia

*Corresponding Author: Email: konstan@uow.edu.au, Phone: +61 242215731

\begin{abstract}
The cytotoxic and genotoxic effects of titanium dioxide $\left(\mathrm{TiO}_{2}\right)$ nanoparticles when exposed to ultraviolet (UV) radiation, particualrly wavelengths between 320-400 nm, has raised concern over their safe use in health and cosmetic related products such as sunscreens. Cerium dioxide $\left(\mathrm{CeO}_{2}\right)$ nanoparticles have been demonstrated to display biocompatible properties and antioxidant activity due to redox cycling of the $\mathrm{Ce}^{3+/} \mathrm{Ce}^{4+}$ oxidation states. In this work, $\mathrm{CeO}_{2} / \mathrm{TiO}_{2}$ nanocomposites were prepared through a standard precipitation method at atomic concentrations (at\%) of Ce relative to Ti of 2.5, 5 and 10 at\%, with the aim of reducing the photocatalytic activity of the core $\mathrm{TiO}_{2}$ nanoparticles and improve biocompatibility. The UV absorptive properties of the nanocomposite samples revealed excellent absorbance across the UV region as compared to pristine $\mathrm{TiO}_{2}$ and $\mathrm{CeO}_{2}$. Furthermore, a drastic reduction in the photocatalysed decomposition of crystal violet, when in the presence of the nanocomposite samples, under both UV and solar simulated light was observed compared to the highly photoactive pristine $\mathrm{TiO}_{2}$. An optimal $\mathrm{CeO}_{2}$ nanodot loading, displaying both high $\mathrm{UV}$ attenuation and
\end{abstract}


low photocatalytic performance was determined at 5 at $\%$ and further in vitro biological testing revealed minimal impact on the cell viability of the human keratinocyte cell line (HaCaT) over a $24 \mathrm{~h}$ period with and without prior exposure to UV irradiation. In contrast, pristine $\mathrm{TiO}_{2}$ nanoparticles induced toxicity to $\mathrm{HaCaT}$ cells with prior UV exposure before incubation, particularly at a dosage of $100 \mathrm{mg}$ $\mathrm{L}^{-1}$. Our findings demonstrate the effectiveness of $\mathrm{CeO}_{2}$ nanodots in improving biocompatibility and its potential as a coating material for active inroganic UV filters.

\section{Introduction}

The detrimental effects of extensive solar ultraviolet (UV) exposure have long been known and include erythema (sunburn), pre-mature skin aging and skin cancer ${ }^{1-3}$. To counteract such adverse effects, the application of sunscreen products containing active UV filtering ingredients is a common means of protection. Such products may contain a combination of inorganic and organic compounds that provide protection through processes of absorption, scattering and reflection of incident UV radiation ${ }^{4}$. Of the inorganic compounds, the mineral compounds of titanium dioxide $\left(\mathrm{TiO}_{2}\right)$ and zinc oxide $(\mathrm{ZnO})$ are most regularly used. Most research surrounding these materials has been conducted for the purpose of utilizing their UV and visible light absorbing capabilities and include light-driven applications such as water splitting, dye sensitized solar cells and self-cleaning glasses ${ }^{5,6}$. However, their high UV blocking potential, chemical inertness and physical stability has also seen their broader commercial use in cosmetic and therapeutic formulations ${ }^{7}$. Initially incorporated into formulations as pigmentary grade particles, recent developments in technology has led to the increased use of nanoparticle materials in the nanoscale size range of $20-50 \mathrm{~nm}$. This in turn has provided sunscreen products with the ability to provide enhanced UV protection, as well as increased cosmetic acceptability of such products by offering transparency in the visible light region ${ }^{8}$. Despite concerns over the potential penetrative ability of these nanoparticles, various dermal penetration studies have concluded that these particles, when in the region of 20-50 nm in size, do not penetrate past the stratum corneum nor reach viable skin cells ${ }^{9-}$ 12. There is, however, conclusive in vitro evidence that shows these materials, as nanoparticles, can impart cytotoxic and genotoxic effects on human cell lines, particularly when exposed to UV radiation

13-15. When excited by UV radiation these materials may instigate the production of free-radical species, 
such as reactive oxygen species (ROS), through the generation of electron/hole $\left(\mathrm{e}^{-} / \mathrm{h}^{+}\right)$pairs. Particularly in the case of $\mathrm{TiO}_{2}$, a well-known and thoroughly used photocatalyst in applications such as dyesensitized solar cells and water splitting, such photocatalytic ability can severely impact the photoprotective ability and length of protection provided by sunscreen products due to potential photodegradation of other organic UV filtering ingredients ${ }^{1,16-18}$. Various other semiconducting transition metal oxide nanoparticles also exhibit extensive UV and visible light absorptive properties, including tungsten oxide $\left(\mathrm{WO}_{3}\right)$, iron oxide $\left(\mathrm{Fe}_{2} \mathrm{O}_{3}\right)$ and tin oxide $\left(\mathrm{SnO}_{4}\right)$, however are also inapplicable in such a sensitive application due to their ROS producing capabilities, accounting for their application in light-driven water-splitting or dye-sensitized solar cells ${ }^{19}$. The production of ROS species can also induce states of oxidative stress in cells if internalized, leading to potential mutagenic effects and premature cell death ${ }^{20,21}$. To counteract these issues, sunscreen manufacturers may incorporate antioxidant compounds or apply inert coatings to the inorganic UV filtering nanoparticles as a means of scavenging and/or minimizing any free radicals produced and potential interactions with other UV filtering ingredients. The issues with these strategies, however, are that the antioxidant compounds used are typically organic, which could increase the probability for an allergic reaction to occur when applied to sensitive skin, whilst coating of $\mathrm{TiO}_{2}$ with materials such as silica $\left(\mathrm{SiO}_{2}\right)$ and alumina $\left(\mathrm{Al}_{2} \mathrm{O}_{3}\right)$ does not necessarily enhance the efficacy of the overall formulation. For instance, various studies have investigated the benefit of applying a silicon-based coating to the surface of photoactive $\mathrm{TiO}_{2}$ nanoparticles, with the subsequent photocatalytic activity appearing to be reduced ${ }^{22-24}$. Despite this reduction, excessive coating can lead to a decrease in the $\mathrm{UV}$ absorptive ability of the core $\mathrm{TiO}_{2}$ particles, thus being detrimental to the overall effectiveness of its use in sunscreen products ${ }^{25}$.

Because of the above, there is still critical need to develop methods or materials that suppress or completely mitigate the photocatalytic ability of these photoactive nanoparticles whilst also simultaneously maintaining or improving the UV attenuation and photostability of the subsequent sunscreen formulation, ideally through some form of free-radical scavenging process. Minimisation or removal of the cytotoxicity and phototoxic potential of these sunscreen-based materials is also an essential component of increasing consumer safety ${ }^{26}$. A promising candidate material that could act as 
both part coating and antioxidant are cerium oxide $\left(\mathrm{CeO}_{2}\right)$ nanoparticles. $\mathrm{CeO}_{2}$ nanoparticles have been investigated previously specifically for potential use as a UV filter in sunscreen products in part due to its UV absorbing ability, as a result of its wide band gap $(3.19 \mathrm{eV}){ }^{27}$. It has also been shown to display free-radical scavenging properties owing to its potential to cycle between the $\mathrm{Ce}^{3+} / \mathrm{Ce}^{4+}$ oxidation states through redox mediated processes ${ }^{28,29}$. In vitro studies involving human cell lines have also shown that $\mathrm{CeO} 2$ imparts relatively low cytotoxic responses and minimal intracellular ROS production, further evidencing its potential in biological oriented applications ${ }^{30-32}$. It has also been shown through biological studies to act as a photo-protectant, specifically against $\mathrm{UVA}^{33}$. Composites of $\mathrm{CeO}_{2}$ with $\mathrm{TiO}_{2}$ have been previously investigated, primarily for use in applications such as visible-light driven photocatalyst ${ }^{34,35}$ and typically involve the formation of core-shell or doped structures ${ }^{36-39}$. However, there are limited reports of this composite material for targeted use in UV filtering applications. One reported study though incorporates $\mathrm{CeO}_{2}$ as a partial coating for iron oxide $\left(\mathrm{Fe}_{2} \mathrm{O}_{3}\right)$ nanoparticles which yielded composite materials displaying improved UV absorbance selectivity and reduced photocatalytic activity through free-radical scavenging ${ }^{40}$. In this manner, the current study presents a material based upon $\mathrm{TiO}_{2}$ nanoparticles encrusted with $\mathrm{CeO}_{2}$ nanodots for the purpose of minimizing free-radical production of the core $\mathrm{TiO}_{2}$ nanoparticles upon UV radiation exposure whilst also maintaining UV attenuating efficiency and reducing any potential cytotoxic and phototoxic effects on the HaCaT human keratinocyte cell line.

\section{Methods}

\section{Synthesis of $\mathrm{CeO}_{2}$ coated $\mathrm{TiO}_{2}$ nanoparticles}

The synthesis of the $\mathrm{CeO}_{2}$ coated $\mathrm{TiO}_{2}$ nanoparticles follows a similar process previously outlined by Cardillo et al, $(2016)^{40}$. In summation, a suspension of the core $\mathrm{TiO}_{2}$ nanoparticles $(0.5 \mathrm{~g})$ (Degussa $\mathrm{P} 25$, Evonik) was prepared in $50 \mathrm{~mL}$ of deionized (DI) water. Relative amounts of cerium (III) nitrate hexahydrate $\left(\mathrm{Ce}\left(\mathrm{NO}_{3}\right)_{3} \cdot 6 \mathrm{H}_{2} \mathrm{O}, 99 \%\right.$, Sigma Aldrich) were added so as to yield relative ratios of the number of $\mathrm{Ce}$ atoms to the number of $\mathrm{Ti}$ atoms (atomic concentration; at $\%$ ) of 2.5, 5 and 10 at $\%$. The suspension was heated to $60^{\circ} \mathrm{C}$ before $1 \mathrm{~mL}$ of concentrated ammonium hydroxide $\left(\mathrm{NH}_{4} \mathrm{OH}, 28.0-\right.$ $30.0 \% \mathrm{NH}_{3}$ basis, Sigma Aldrich) was added drop wise, followed by the addition of $1 \mathrm{~mL}$ of hydrogen 
peroxide $\left(\mathrm{H}_{2} \mathrm{O}_{2}, 30 \mathrm{wt} \%\right.$ in $\mathrm{H}_{2} \mathrm{O}$, Sigma Aldrich). The precipitants were collected via centrifugation $(12,840 \times \mathrm{g}$ for $10 \mathrm{~min})$ and washed several times with DI water and ethanol $\left(\mathrm{CH}_{3} \mathrm{CH}_{2} \mathrm{OH}, 96 \%\right.$, ChemSupply) before being dried at $100^{\circ} \mathrm{C}$ overnight and ground into a fine powder. A sample of purely $\mathrm{CeO}_{2}$ was prepared in the same manner as described in absence of the core $\mathrm{TiO}_{2}$ nanoparticles.

\section{Characterization of structural and crystallographic properties}

X-ray diffraction (XRD) patterns were collected for the prepared samples using a MAC Science MO3xHF22 (MAC Science Ltd.) scanning between $2 \theta=20-90^{\circ}$ at a scan speed of $1.5^{\circ} \mathrm{min}^{-1}$ and step size of $0.020^{\circ}$. The emission source used was a $\mathrm{Cu} \mathrm{K} \alpha$ radiation source $(\lambda=0.15405 \mathrm{~nm})$. Transmission electron microscopy (TEM) and energy dispersive spectroscopy (EDS) was also performed on the prepared samples using a JEM-2011 transmission electron microscope (JEOL) coupled with a $30 \mathrm{~mm}^{2}$ JEOL JED-2300 EDS detector.

\section{Characterization of optical absorbance and band gap}

Absorbance spectra were collected using a UV-1800 spectrophotometer (Shimadzu). Nanoparticle and nanocomposite samples were dispersed in $\mathrm{CH}_{3} \mathrm{CH}_{2} \mathrm{OH}$ and homogenized via sonication (Branson 3800, Ultrasonics Corp.) for an hour prior to analysis. Additionally, the extinction coefficient for each sample was calculated from the calibration curve obtained from measuring the absorbance spectra at a range of concentrations. Using the Beer-Lambert law:

$$
\mathrm{A}=\varepsilon l \mathrm{c}
$$

where $\mathrm{A}$ is the absorbance (a.u.), 1 the path length (cm), c the concentration (mg L-1) and $\varepsilon$ the extinction coefficient $\left(\mathrm{L} \mathrm{mg}^{-1} \mathrm{~cm}^{-1}\right)$, with $\varepsilon$ determined from the slope of the curves obtained . Furthermore, the optical band gap of each sample was determined using the Tauc relation:

$(\alpha h v)^{\mathrm{n}}=\mathrm{A}\left(\mathrm{hv}-\mathrm{E}_{\mathrm{g}}\right)$

where $\alpha$ is the absorption coefficient $\left(\mathrm{cm}^{-1}\right), \mathrm{A}$ an arbitrary constant, hv the photon energy $(\mathrm{eV}), \mathrm{E}_{\mathrm{g}}$ the band gap and $n$ the nature of transition between electronic band states. For the case of $\mathrm{TiO}_{2}$ and $\mathrm{CeO}_{2}$, a value of $n=2$ was used, corresponding to a direct transition type. A plot consisting of $(\alpha h v)^{n}$ against 
hv and extrapolating the linear region of the curve produced to the $\mathrm{x}$-axis yields an estimation of the optical band gap.

\section{Evaluation of photocatalytic activity}

The photocatalytic activities of the prepared nanoparticle samples were evaluated using the aqueous triarylmethane dye, crystal violet (CV) $\left(\mathrm{C}_{25} \mathrm{H}_{30} \mathrm{ClN}_{3}, \geq 90 \%\right.$, Sigma-Aldrich). An RPR-200 photocatalytic reactor (Rayonet) lined with $350 \mathrm{~nm}$ and $300 \mathrm{~nm}$ phosphor-coated lamps were used as the irradiation source. A $100 \mathrm{~mL}$ suspension of the nanoparticle sample being tested $\left(5 \mathrm{mg} \mathrm{L}^{-1}\right)$ was prepared in a solution of the dye ( $5 \mathrm{mg} \mathrm{L}-1)$ and transferred to a quartz beaker and left to stir in darkness for $30 \mathrm{~min}$. The mixture was then irradiated for a period of $60 \mathrm{~min}$ and $10 \mathrm{~mL}$ aliquots collected periodically every $10 \mathrm{~min}$. The resultant degradation was assessed via UV-Vis spectroscopy using a UV-1800 Spectrophotometer (Shimadzu) by measuring the changes in the major absorbance peak of the dye $(\lambda=590 \mathrm{~nm})$. The photocatalytic capabilities of the prepared materials were further assessed under a simulated solar spectrum. A halogen lamp (50 W power) was used, and the degradation of the CV dye measured through irradiation by AM $1.5 \mathrm{G}$ one sun $\left(1000 \mathrm{~mW} \mathrm{~cm} \mathrm{c}^{-2}\right)$ for a period of $4 \mathrm{~h}$ and sampling points of $30 \mathrm{~min}$. Each nanoparticle and nanocomposite sample was tested in three separate experiments, for both UV and solar-simulated light exposure, and the mean degradation at each time interval taken.

\section{Cell culture}

The adherent immortalized human keratinocyte cell line, $\mathrm{HaCaT}^{41}$, was used for all cell culture experiments and were originally provided by Dr. J. Guy Lyons (University of Sydney). Short Tandem Repeat Profiling (Garvan Institute of Medical Research) verified the identity of the cells. The cells were maintained in phenol red Dulbecco's Modified Eagle Medium/Nutrient Mixture F-12 (DMEM/F12, Thermo Fisher Scientific) supplemented with 10\% (v/v) heat inactivated fetal bovine serum (FBS, Bovogen Biologicals), $100 \mathrm{U} \mathrm{mL}^{-1}$ penicillin/100 $\mu \mathrm{g} \mathrm{mL}^{-1}$ streptomycin (Thermo Fisher Scientific) and $2 \mathrm{mM}$ GlutaMAXTM (Thermo Fisher Scientific) and incubated at $37^{\circ} \mathrm{C}$ with $5 \%(\mathrm{v} / \mathrm{v}) \mathrm{CO}_{2}$ in $75 \mathrm{~cm}^{2}$ tissue culture flasks (Greiner Bio-One). Cells were passaged twice weekly when the confluency of cells 
had reached $\geq 90 \%$. Cells were routinely negative for mycoplasma (MycoAlert Mycoplasma Detection Kit, Lonza).

In vitro cell viability assays with/without $U V$ irradiation

The viability of the HaCaT cell line under the influence of the selected nanoparticle and nanocomposites samples was tested using the MTS assay kit (CellTiter $96^{\circledR}$ AQueous One Solution Cell Proliferation Assay Kit, Promega). In a typical MTS assay, $100 \mu \mathrm{L}$ of the cells were seeded in a 96 -well plate at a concentration of $8-10 \times 10^{3}$ cells well ${ }^{-1}$ and incubated for $24 \mathrm{~h}$ at $37^{\circ} \mathrm{C}$ with $5 \%(\mathrm{v} / \mathrm{v}) \mathrm{CO}_{2}$ to enable adhesion to the bottom of the wells. Suspensions of the prepared nanocomposite and pristine nanoparticle samples were prepared in the same complete medium used for culturing the cells and sonicated for $1 \mathrm{~h}$ to give a concentration of

$500 \mathrm{mg} \mathrm{L}^{-1}$. The suspensions were then further diluted and added to the wells containing cells at concentrations of $0,1,3,10,30,100$ and $300 \mathrm{mg} \mathrm{L}^{-1}$, before incubation for $24 \mathrm{~h}$ at $37^{\circ} \mathrm{C}$ with $5 \%(\mathrm{v} / \mathrm{v})$ $\mathrm{CO}_{2}$. A volume of $20 \mu \mathrm{L}$ of MTS reagent was then added to each well tested after $20 \mathrm{~h}$ before being incubated a further $4 \mathrm{~h}$ to enable colour development. The plates were centrifuged at $750 \times \mathrm{g}$ for $10 \mathrm{~min}$ and $80 \mu \mathrm{L}$ aliquots were transferred to a new plate and read using a microplate reader (SpectraMax 384 Plus, Molecular Devices) at $\lambda=490 \mathrm{~nm}$. Each assay was performed in triplicate for each tested material and repeated in three separate experiments, with the data presented as the change in $\mathrm{HaCaT}$ cell viability (\% of control) with change in sample concentration.

The photo-induced toxicity of the nanoparticle and nanocomposite samples were also examined. In these experiments, cells were seeded at an initial density of $30 \times 10^{3}$ cells well ${ }^{-1}$ and $100 \mu \mathrm{L}$ volume and allowed to adhere and grow for $24 \mathrm{~h}$. Due to the nature of the experimental design and variance of the lamp intensity with distance, three concentrations were chosen, namely, 25, 50 and $100 \mathrm{mg} \mathrm{L}^{-1}$. After the initial $24 \mathrm{~h}$ incubation period, nanoparticle suspensions were prepared in Dulbecco's phosphate buffered saline (DPBS, no $\mathrm{Ca}^{2+}$ or $\mathrm{Mg}^{2+}$, Thermo Fisher Scientific) and sonicated for $1 \mathrm{~h}$ at a concentration of $500 \mathrm{mg} \mathrm{L}^{-1}$. All media was removed from test wells and replaced with a mixture of DPBS and the nanoparticle/nanocomposite sample being tested, so as to yield the desired concentration 
and total volume of $100 \mu \mathrm{L}$. The particles were allowed to settle for $1 \mathrm{~h}$ to enable interaction with the cells and to form a film atop of the adherent cell line. A $300 \mathrm{~W}$ sunlamp (Ultra-Vitalux, OSRAM) was used as the light source and was pre-run for $1 \mathrm{~h}$ to allow for output stabilization. The emission profile for the sunlamp is given in Fig S1. The UVA/UVB light intensity of the sunlamp was measured using a UV detector (Model 850009, Sper Scientific). The open plates containing the nanoparticles and cells were exposed to the light source for either 5 or $15 \mathrm{~min}$ at an intensity of $6 \mathrm{~mW} \mathrm{~cm}{ }^{-2}$ whilst sitting atop an ice block so as to minimize the effects of heat generated by the lamp. After the exposure period, all DPBS from each well used was removed and replaced with $100 \mu \mathrm{L}$ of fresh complete medium. The cells with the nanoparticles tested were incubated together for a further $24 \mathrm{~h}$ and the cell viability assessed in the same manner as outlined for the assays in absence of the UV source. A control plate consisting of $\mathrm{HaCaT}$ cells was prepared concurrently and treated in the same manner as the test plates without exposure to the sunlamp. The reduction in cell viability, as measured through absorbance readings at $\lambda=490 \mathrm{~nm}$, for all wells exposed to UV was normalized to the cell viability of the control plate in absence of UV exposure and presented as the change in HaCaT cell viability (\% of control) at differing sample concentrations. Each nanoparticle and nanocomposite sample were tested in triplicate per experiment and three experiments performed for each concentration tested.

\section{Data presentation and statistical analysis}

Data is presented as mean \pm standard error of mean (SEM). One-way ANOVA and Tukey post-hoc statistical analysis was performed to assess statistical differences between the nanoparticle and nanocomposites samples tested using OriginPro. Statistical significance was determined at the $95 \%$ and 99\% confidence levels ( $\mathrm{p}<0.05$ and $\mathrm{p}<0.01$, respectively). 


\section{Results and Discussion}

Figure 2 highlights the XRD patterns obtained for the nanocomposite and pristine $\mathrm{CeO}_{2} / \mathrm{TiO}_{2}$ samples prepared. For the pristine $\mathrm{TiO}_{2}(\mathrm{P} 25)$, the diffraction pattern obtained corresponds to a mixed phase of anatase (PDF card 03-065-5714) and rutile (PDF card 03-065-1119) crystal forms, as has been previously reported for Degussa $\mathrm{P} 25 \mathrm{TiO}_{2}{ }^{42}$. The peak broadening observed for the anatase and rutile reflections in each of the $\mathrm{TiO}_{2}$ containing samples is also indicative of the nanocrystalline nature of the core material, as evidenced by the mean crystal size of $27 \pm 3 \mathrm{~nm}$, calculated from the Scherrer equation and the full-width half maximum (FWHM) of the anatase (101) reflection (Equation S1). As for the pristine $\mathrm{CeO}_{2}$ sample, the pattern obtained was identified as the cubic (fluorite) (PDF card 01-089-8436) crystal phase, with broad diffraction peaks similarly due to the nanocrystalline nature of the particles produced $(4.8 \pm 0.9 \mathrm{~nm})^{43}$. In the case of the nanocomposite samples, there is little variation between the patterns obtained, particularly in the case of the 2.5 at $\%$ and 5 at $\%$ samples, and no evidence of a secondary phase corresponding to $\mathrm{CeO}_{2}$ is evident. However, for the 10 at\% nanocomposite sample, a shoulder appears off the (110) rutile reflection at approximately $2 \theta=28^{\circ}$, corresponding to the (111) $\mathrm{CeO}_{2}$ crystal plane, likely a result of the increased $\mathrm{CeO}_{2}$ loading.

Surface composition analysis performed using high resolution XPS further reveals the presence of Ce in the nanocomposite samples. Figure 3 highlights the Ti $2 p$ and Ce $3 d$ spin-orbit splitting regions for each of the nanocomposite and pristine $\mathrm{CeO}_{2} / \mathrm{TiO}_{2}$ samples. Peak deconvolution of the Ti $2 p$ region for pristine $\mathrm{TiO}_{2}(\mathrm{P} 25)$ (Fig. 3 a) reveals the presence of a doublet pair corresponding to the $2 p_{1 / 2}$ and $2 p_{3 / 2}$ degenerate electron spin states of the tetravalent titanium $\left(\mathrm{Ti}^{4+}\right)$ ion ${ }^{44}$.

In addition, the energy separation $(\Delta \mathrm{E}=5.91 \mathrm{eV})$ between the In addition, the energy separation $(\Delta \mathrm{E}=$ $5.91 \mathrm{eV})$ between the two peak positions for the $2 p_{1 / 2}(463.9 \mathrm{eV})$ and $2 p_{3 / 2}(457.9 \mathrm{eV})$ peaks agree well with those previously reported for $\mathrm{P} 25^{45,46}$. No peaks due to splitting of Ce $3 d$ orbitals was observed for the pristine $\mathrm{TiO}_{2}(\mathrm{P} 25)$, as expected. In the case of the pristine $\mathrm{CeO}_{2}$ sample (Fig. 3 e), a six peak Ce $3 d$ splitting pattern was observed. Peak deconvolution yielded three pairs of $d$ orbital emission doublets with spin states of $\mathrm{j}=3 / 2$ or $5 / 2$ attributed to tetravalent $\mathrm{Ce}\left(\mathrm{Ce}^{4+}\right)$ along with two doublet pairs attributed to trivalent $\mathrm{Ce}\left(\mathrm{Ce}^{3+}\right)$. The presence of these mixed oxidation states in nanoparticulate $\mathrm{CeO}_{2}$ has been 
previously reported, although no evidence of $\mathrm{Ce}_{2} \mathrm{O}_{3}$ is observed through XRD (Fig. 2) ${ }^{47}$. This could be due to a combination of the small crystal size of the material leading to significant peak broadening and a low amount of $\mathrm{Ce}_{2} \mathrm{O}_{3}$ relative to $\mathrm{CeO}_{2}$, resulting in a masking of the $\mathrm{Ce}_{2} \mathrm{O}_{3}$ contributions to the XRD pattern ${ }^{48,49}$. As is expected, no evidence of $\mathrm{Ti}$ is observed in the pristine $\mathrm{CeO}_{2}$ sample. XPS spectra of the nanocomposite samples highlight peaks from both the Ti $2 p$ and $\mathrm{Ce} 3 d$ orbitals of $\mathrm{TiO}_{2}$ and $\mathrm{CeO}_{2}$. In addition, the intensity of both the Ti $2 p$ and $\mathrm{Ce} 3 d$ peaks vary according to the loading of $\mathrm{CeO}_{2}$. As the loading of $\mathrm{CeO}_{2}$ increases, the intensity of the $\mathrm{Ce} 3 d$ peaks increases whilst, conversely, the Ti $2 p$ peak intensities decrease accordingly. Furthermore, it is evident in the 10 at $\% \mathrm{CeO}_{2} / \mathrm{TiO}_{2} \mathrm{XPS}$ spectra that $\mathrm{Ce}$ is present as a mixture of the $3+/ 4+$ oxidation state. Although deconvolution yielding peaks due to $\mathrm{Ce}^{3+}$ spin states become less clear in the 2.5 at $\%$ and 5 at $\%$ nanocomposite samples, considering that the synthesis method employed for preparing the nanocomposites relative to the pristine $\mathrm{CeO}_{2}$ is the same, it can be inferred that the Ce present in these samples also exists as some ratio of the $3+/ 4+$ oxidation states.

Table 1 and Figures 1, 4 and 5 list and highlight the results obtained from the EDS/TEM analysis. The Ce atomic concentrations for the nanocomposite samples were determined to be $1.4 \pm 0.3,4 \pm 1$ and $11 \pm 5$ at $\%$ for the 2.5, 5 and 10 at $\%$ nanocomposite samples, which are in reasonable agreement with the desired concentrations. In addition to the Ce content, the mapped images also provide an indication of the quality of the $\mathrm{CeO}_{2}$ nanodot encrusting process. For each sample, it is evident from the images obtained (Fig. 5) that the $\mathrm{CeO}_{2}$ nanoparticles tended to precipitate as clusters as opposed to a layered coating atop the core $\mathrm{TiO}_{2}$ particle surface. The $\mathrm{Ce}^{3+}$ ions from the nitrate precursor appear to have coordinated towards the surface of the core $\mathrm{TiO}_{2}$ nanoparticles prior to precipitation and resulting in the clustering of $\mathrm{CeO}_{2}$ nanoparticles after the addition of $\mathrm{NH}_{4} \mathrm{OH}$, as illustrated in Figure 1. This was expected, particularly for the 2.5 and 5 at $\% \mathrm{CeO}_{2} / \mathrm{TiO}_{2}$ samples, due to the low $\mathrm{CeO}_{2}$ loading applied. However, this was also observed for the higher concentration 10 at $\% \mathrm{CeO}_{2} / \mathrm{TiO}_{2}$ sample where this clustering or agglomeration was most prominent, suggesting even at 10 at $\%$, higher concentrations of $\mathrm{CeO}_{2}$ would be needed for full coverage. The addition of some form of surfactant or binding agent to the surface of the core $\mathrm{TiO}_{2}$ nanoparticles prior to precipitation may have aided in reducing 
agglomeration of the $\mathrm{CeO}_{2}$ nanoparticles and in obtaining a more uniform coating or deposition of the $\mathrm{CeO}_{2}$ nanodots. However, complete coverage of the core $\mathrm{TiO}_{2}$ nanoparticles could also affect the performance of the nanocomposite materials in terms of UV attenuation. Reducing the surface area of exposed $\mathrm{TiO}_{2}$ in the nanocomposite samples would likely result in reduced UV absorption performance, particularly in the important UVB (290-320 nm) and UVA $(320-400 \mathrm{~nm})$ wavelength bands associated with sun damaging effects.

The mean size of the $\mathrm{CeO}_{2}$ nanodots formed on the surface of the core $\mathrm{TiO}_{2}$ nanoparticles of the 10 at $\%$ $\mathrm{CeO}_{2} / \mathrm{TiO}_{2}$ nanocomposite sample were measured and averaged. The mean size calculated for this sample corresponded to $4.6 \pm 0.8 \mathrm{~nm}$ (Fig. 4). This value also corroborates with the mean crystallite size of $4.8 \pm 0.5 \mathrm{~nm}$, calculated from the pristine $\mathrm{CeO}_{2}$ XRD pattern using the Scherrer equation. It has been reported that the size of $\mathrm{CeO}_{2}$ nanoparticles is important in terms of its redox activity and contributes to the coexistence of the $3+/ 4+$ oxidation states of $\mathrm{Ce}$ and the presence of $\mathrm{Ce}^{3+}$ surface sites and oxygen vacancies ${ }^{50}$. This is thought to bring about the prominent antioxidant properties of these nanoparticles and their ability to scavenge $\mathrm{ROS}^{51}$. It has been predominantly found that, as the size of the $\mathrm{CeO}_{2}$ nanoparticle decreases, an increase in the antioxidant activity is observed ${ }^{40,50,52}$. In the case of the 2.5 at $\%$ and 5 at $\% \mathrm{CeO}_{2} / \mathrm{TiO}_{2}$ samples the particles of $\mathrm{CeO}_{2}$ present appear to be smaller than those found in the 10 at\% sample, suggesting sizes below a mean of approximately $5 \mathrm{~nm}$. This could lead to a further increase in the presence of surface $\mathrm{Ce}^{3+}$ sites that contribute to the ROS scavenging ability of these materials at these loading concentrations.

Dilute UV-Vis absorption spectroscopy was performed to ascertain the effects of ceria loading on the optical absorption properties of the nanocomposite materials. Figure 7 highlights the absorption spectra obtained for the nanocomposite materials, as well as the pristine $\mathrm{CeO}_{2}$ and $\mathrm{TiO}_{2}(\mathrm{P} 25)$ nanoparticles for $30 \mathrm{mg} \mathrm{L}^{-1}$ suspensions prepared in $\mathrm{CH}_{3} \mathrm{CH}_{2} \mathrm{OH}$. Values for the extinction coefficients $(\varepsilon)$ were calculated from calibration curves (Fig. S2 and Fig.7 b) for each sample and were determined to be 
$44 \pm 1 ; 21.9 \pm 0.7 ; 28.6 \pm 0.6 ; 20.0 \pm 0.4$ and $10.9 \pm 0.3 \times 10-3 \mathrm{~L} \mathrm{mg}^{-1} \mathrm{~cm}^{-1}$ for $\mathrm{TiO}_{2}(\mathrm{P} 25)$, the 2.5 at $\%, 5$ at $\%$ and 10 at $\% \mathrm{CeO}_{2} / \mathrm{TiO}_{2}$ nanocomposites and $\mathrm{CeO}_{2}$, respectively. For the pristine $\mathrm{CeO}_{2}$ nanoparticles, the absorbance and extinction coefficient $\left(\varepsilon=10.9 \pm 0.3 \times 10^{-3} \mathrm{~L} \mathrm{mg}^{-1} \mathrm{~cm}^{-1}\right)$ relative to the other nanoparticle and nanocomposite samples is considerably lower, with the major absorbance peaking at the higher energy end of the UVB region ( $\sim 305 \mathrm{~nm})$. For each of the $\mathrm{TiO}_{2}$ containing samples tested, the primary absorption band was observed within the UVB region, with the major peak absorption spanning between $290-320 \mathrm{~nm}$, although substantial absorbance is also observed within the UVA region, accounting for its commercial use in commercial UV filtering products.

Table 1: Experimental results for the nanocomposite and pristine samples prepared, detailing Eg and $\varepsilon$ values calculated from absorbance spectra.

\begin{tabular}{llll}
\hline Sample & $E_{g}(\mathrm{eV})$ & $\varepsilon\left(\mathrm{L} \mathrm{mg}^{-1} \mathrm{~cm}^{-1}\right)\left(\times 10^{-3}\right)^{\mathrm{a}}$ & $\mathrm{Ce} / \mathrm{Ti}(\mathrm{at} \%)^{\mathrm{b}}$ \\
\hline $\mathrm{TiO} 2(\mathrm{P} 25)$ & $3.30 \pm 0.02$ & $44 \pm 1$ & $\mathrm{~N} / \mathrm{A}$ \\
$2.5 \mathrm{at} \% \mathrm{CeO} 2 / \mathrm{TiO} 2$ & $3.23 \pm 0.01$ & $21.9 \pm 0.7$ & $1.4 \pm 0.3$ \\
$5 \mathrm{at} \% \mathrm{CeO} 2 / \mathrm{TiO} 2$ & $3.26 \pm 0.02$ & $28.6 \pm 0.6$ & $4 \pm 1$ \\
$10 \mathrm{at} \% \mathrm{CeO} 2 / \mathrm{TiO} 2$ & $3.21 \pm 0.01$ & $20.0 \pm 0.4$ & $11 \pm 5$ \\
$\mathrm{CeO} 2$ & $3.28 \pm 0.01$ & $10.9 \pm 0.3$ & $\mathrm{~N} / \mathrm{A}$ \\
\hline
\end{tabular}

${ }^{\text {a }}$ These values correspond to extinction coefficients calculated at the wavelengths of maximum absorption for each sample at a concentration of $30 \mathrm{mg} \mathrm{L-1} .{ }^{\mathrm{b}}$ Atomic loadings as determined from EDS analysis. The errors shown are the standard deviation between triplicate measurements.

The lower absorbance and extinction values for the nanocomposite samples, as compared to the pristine $\mathrm{TiO}_{2}(\mathrm{P} 25)$ nanoparticles would indicate minimal synergistic effect from the $\mathrm{CeO}_{2}$ coupling concerning these optical properties. Furthermore, as mentioned previously, the lower optical performance for the nanocomposite samples could be attributed to the reduction in $\mathrm{TiO}_{2}$ surface area exposed to the incident light source, thus lower absorption contributed by the $\mathrm{TiO}_{2}$. Despite displaying lower absorbance than the pristine $\mathrm{TiO}_{2}(\mathrm{P} 25)$, the nanocomposite samples still display substantial UV absorption, highlighting 
their promise as UV protection agents. They also display a higher degree of transparency in the visible light region (400-700 nm) compared to the pristine $\mathrm{TiO}_{2}$ (P25), making them cosmetically advantageous for use in sunscreen formulations. Notably, the extinction coefficient increased from 2.55 at $\% \mathrm{CeO}_{2}$ loading but decreased between the 5 and 10 at $\%$ samples. The respective increase and decrease suggests that some optimal $\mathrm{CeO}_{2}$ loading amount aids in improving the $\mathrm{UV}$ attenuation of the core material, as evidenced by the improvement between the 2.5 at $\%$ and 5 at $\%$ samples in absorbance across the UV region. However, further loading of $\mathrm{CeO}_{2}$ in the 10 at\% sample increases the surface coverage of the core $\mathrm{TiO}_{2}$ nanoparticles. As such, any synergistic effects imparted by the $\mathrm{CeO}_{2} / \mathrm{TiO}_{2}$ coupling towards $\mathrm{UV}$ attenuation is being mitigated by the reduction in available $\mathrm{TiO}_{2}$ surfaces available for efficient absorption. Band gap values were calculated for each sample from their corresponding Tauc plots (Fig. S3) and are listed in Table 1. The band gap ( $\left.E_{\mathrm{g}}\right)$ value of $3.30 \pm 0.02 \mathrm{eV}$ for the pristine $\mathrm{TiO}_{2}(\mathrm{P} 25)$ nanoparticles is in reasonable agreement with other reported findings for the commercial product ${ }^{53}$. A slightly lower $\mathrm{E}_{\mathrm{g}}$ value was obtained for the pristine $\mathrm{CeO}_{2}$ nanoparticles $(3.28 \pm 0.01 \mathrm{eV})$ as compared to $\mathrm{TiO}_{2}(\mathrm{P} 25)$. As with the extinction coefficients and absorbance efficiencies, the $\mathrm{E}_{\mathrm{g}}$ values tended to increase from $2.5-5$ at $\% \mathrm{CeO}_{2}$, then decreased again at a $\mathrm{CeO}_{2}$ loading of 10 at $\%$. However, the separation between $\mathrm{E}_{\mathrm{g}}$ values calculated from the nanocomposite samples only vary between $1-3 \%$, which is insubstantial to suggest major modification to the core $\mathrm{TiO}_{2}$ nanoparticles due to the $\mathrm{CeO}_{2}$ loading. This could be considered beneficial, in the sense that $\mathrm{TiO}_{2}$ is already considered a highly effective UVB absorber and so, keeping the $\mathrm{E}_{\mathrm{g}}$ of the nanocomposite materials to within this range is beneficial for ensuring suitable UV filtration when employed in sun protecting products.

The photocatalytic activities of the nanocomposite samples were evaluated by measuring the degradation of $\mathrm{CV}$ dye under UV and solar-simulated light irradiation over a period of 1 and $4 \mathrm{~h}$, respectively. The degradation kinetics in such dye-photocatalyst systems have been previously ascribed to follow a pseudo-first-order reaction rate as according to the Langmuir-Hinshelwood model ${ }^{54}$. 
Through this model, a simplified expression is generated when the initial concentration of dye $\left(\mathrm{C}_{\mathrm{o}}\right)$ is small and presented as follows:

$$
\ln \left(\mathrm{C}_{\mathrm{o}} / \mathrm{C}\right)=\mathrm{k}_{\mathrm{app}} \mathrm{t}
$$

Where $\mathrm{C}$ is the concentration of the dye at a given time $\mathrm{t}(\mathrm{min})$ and $\mathrm{k}_{\mathrm{app}}$ the apparent rate constant ( $\mathrm{min}^{-}$ 1). Figure 8 a and Table 2 highlight the photodegradation efficiencies and rate constants determined for the degradation of $\mathrm{CV}$ in the presence of the nanocomposite and pristine powder samples under UV irradiation. Of the samples tested, pristine $\mathrm{TiO}_{2}$ (P25) nanoparticles displayed the highest degradation rate $\left(\mathrm{k}_{\text {app }}=53.8 \pm 2.0 \times 10^{-3} \mathrm{~min}^{-1}\right)$, nearly completely degrading the $\mathrm{CV}$ dye within the $1 \mathrm{~h}$ irradiation time. The photocatalytic degradation of dyes in the presence of $\mathrm{TiO}_{2}$ has been thoroughly studied, and it is well understood that, upon excitation by photons higher in energy than its respective band gap, the formation of photoexcited $\mathrm{e}^{-} / \mathrm{h}^{+}$pairs occurs ${ }^{54-56}$. These photoexcited species can then reduce/oxidise the dye directly or interact with dissolved oxygen $\left(\mathrm{O}_{2}\right)$ or other oxygen containing species present, such as water $\left(\mathrm{H}_{2} \mathrm{O}\right)$, to produce ROS that cause degradation indirectly. The efficiency of this degradation process is strongly dependent on the recombination rate of these photoexcited species as a percentage of the incident photon rate, known as photonic efficiency ${ }^{57}$. $\mathrm{TiO}_{2}$ has been shown to have a relatively high photonic efficiency in comparison to other semiconducting materials which, combined with its relatively cheap manufacturing, explains its extensive use and study in photocatalysis. Furthermore, the mixed anatase/rutile composition of the $\mathrm{TiO}_{2}(\mathrm{P} 25)$ tested has also been previously shown to display photodegradation efficiencies greater than either single phase ${ }^{58}$. The 2.5 at $\% \mathrm{CeO}_{2} / \mathrm{TiO}_{2}$ nanocomposite exhibited the second highest degradation rate $\left(11.7 \pm 0.6 \times 10^{-3} \mathrm{~min}^{-1}\right)$ and reduced the dye concentration to approximately $50 \%$. For the remaining samples, very low degradation rates were observed with $\mathrm{k}_{\text {app }}$ values of $1.3 \pm 0.2,0.9 \pm 0.1$ and $0.5 \pm 0.1 \times 10^{-3} \mathrm{~min}^{-1}$ determined for the 5 at $\% \mathrm{CeO}_{2} / \mathrm{TiO}_{2}, 10$ at $\%$ $\mathrm{CeO}_{2} / \mathrm{TiO}_{2}$ and pristine $\mathrm{CeO}_{2}$ samples, respectively.

The substantial reduction in photoactivity for the nanocomposite and pristine $\mathrm{CeO}_{2}$ could, in part, be attributed to the lower UV absorbing capabilities of these materials in comparison to pristine $\mathrm{TiO}_{2}(\mathrm{P} 25)$ 
(Fig. 7 a), however, one particular nanocomposite stands out from the rest. The near negligible degradation observed in the case of the 5 at $\%$ nanocomposite does not coincide with its still relatively high UV absorbance properties. Combined with the minimal modification seen in the band gap of this nanocomposite compared to the pristine $\mathrm{TiO}_{2}(\mathrm{P} 25)$ sample, the low photoactivity observed could be attributed to a reduction in ROS generation (due to increased recombination of charge carriers) or ROS scavenging (due to the presence of $\mathrm{CeO}_{2}$ ). For the latter case, it could be suggested that the effect is dependent on the loading of $\mathrm{CeO}_{2}$. Despite displaying lower UV absorbance efficiency than the 5 at\% nanocomposite, the 2.5 at $\%$ sample displayed much higher photoactivity under UV irradiation $\left(\mathrm{k}_{\text {app }}=\right.$ $11.7 \pm 0.6 \times 10^{-3} \mathrm{~min}^{-1}$ compared to $\left.\mathrm{k}_{\text {app }}=1.3 \pm 0.2 \times 10^{-3} \mathrm{~min}^{-1}\right)$. This could suggest that at this $\mathrm{CeO}_{2}$ loading ratio, the ability for the $\mathrm{CeO}_{2}$ present to act as an antioxidant is outweighed by the photocatalytic activity of the core $\mathrm{TiO}_{2}$, in spite of the lower absorptive properties. However, as the $\mathrm{CeO}_{2}$ loading is increased, a drastic reduction in degradation is observed as well as a peaking in UV absorbance for the 5 at\% loaded sample before decreasing again in the 10 at $\%$ loaded sample. It is thus evident that there is a trade-off between obtaining the antioxidant properties of the $\mathrm{CeO}_{2}$ surface loaded nanoparticles with maintaining adequate $\mathrm{UV}$ protection afforded mainly by the core $\mathrm{TiO}_{2}$ nanoparticles and is influenced by the loading concentration. Figure $8 \mathrm{~b}$ highlights the photodegradation results for the samples tested when exposed to solar simulated light. In a similar manner to the UV photodegradation tests, the pristine $\mathrm{TiO}_{2}(\mathrm{P} 25)$ displayed vastly superior photocatalytic activity $\left(\mathrm{k}_{\text {app }}=8.16 \pm 0.17 \times 10^{-3} \mathrm{~min}^{-1}\right)$ as compared to the nanocomposite and pristine $\mathrm{CeO}_{2}$ samples. Furthermore, the photocatalytic activity of the nanocomposite samples under solar simulated light follows the same trend observed when exposed to only UV radiation, with greater $\mathrm{CeO}_{2}$ loading leading to a lower perceived activity $\left(\mathrm{k}_{\text {app }}=1.43 \pm 0.03\right.$, $0.62 \pm 0.04,0.44 \pm 0.04 \times 10^{-3} \mathrm{~min}^{-1}$ for the 2.5 at $\%, 5$ at $\%$ and 10 at $\% \mathrm{CeO}_{2} / \mathrm{TiO}_{2}$ nanocomposite samples, respectively). Similarly, the reasons for this trend across the nanocomposite samples are likely similar to those outlined previously for the UV photodegradation results since there is little direct absorbance within the visible light region for the nanocomposite samples from which changing the light source can have a major impact. 
Notably, the pristine $\mathrm{CeO}_{2}$ sample when exposed to simulated solar light displayed an enhancement in photoactivity as compared to when exposed purely to UV, but still afforded some protection for the dye itself against decomposition by solar simulated light. A possible explanation as to why the protective effect of $\mathrm{CeO}_{2}$ in this case is not as pronounced as compared to the nanocomposite samples, where the $\mathrm{CeO}_{2}$ loading is significantly lower, could be due to the influence of surface defects and surface defect concentration. The main type of surface defect that occurs with ceramic nanoparticles are oxygen vacancies which, in the case of $\mathrm{CeO}_{2}$, results in the reduction of surface $\mathrm{Ce}^{4+}$ to $\mathrm{Ce}^{3+}$, so as to compensate for the effects of electrostatic forces. The presence of these surface based $\mathrm{Ce}^{3+}$ states suggests the presence of $\mathrm{Ce}_{2} \mathrm{O}_{3}$, a phase not observed in $\mathrm{XRD}$ analysis of the pristine $\mathrm{CeO}_{2}$ since it is limited to the surface and likely masked by the higher volume loaded $\mathrm{CeO}_{2}$ phase. $\mathrm{Ce}_{2} \mathrm{O}_{3}$ enables the absorption of visible light wavelengths and has been reported to have a significantly smaller band gap than $\mathrm{CeO}_{2}$ of $2.40 \mathrm{eV}^{59,60}$. The reason such absorption features were not evidenced in the absorption spectra of $\mathrm{CeO}_{2}$ could be attributed to the very fact that it is a phenomenon strictly limited to the surface of the $\mathrm{CeO}_{2}$ nanoparticles, whereas absorption spectroscopy considers the entire bulk. Because of the additional limited visible light absorption afforded, the $\mathrm{CeO}_{2}$ scavenging capabilities are also in direct competition with the photocatalytic properties of the material from both UV and visible light excitation. However, the contribution to photocatalysis due to visible light excitation in pristine $\mathrm{CeO}_{2}$ is still not so significant since the dye itself is still afforded some protection over the $4 \mathrm{~h}$ exposure period as compared to the dye degradation in absence of any catalyst. This effect is also further limited in the case of the nanocomposite samples due to the reduced loading of $\mathrm{CeO}_{2}$ in these samples relative to the pristine $\mathrm{CeO}_{2}$ and thus a more pronounced reduction in photocatalytic activity is observed instead.

It can be concluded from these photodegradation experiments that the application of $\mathrm{CeO}_{2}$ to the surface of highly photoactive $\mathrm{TiO}_{2}$ nanoparticles can influence the photocatalytic performance. The drastic reduction in photocatalytic activity observed for the nanocomposite samples relative to the pristine $\mathrm{TiO}_{2}$ (P25) sample adds further evidence towards to the potential of $\mathrm{CeO}_{2}$ as new additive coating material for inorganic UV filters. 
Table 2: Photodegradation data detailing the CV degradation percentage and rate of degradation, $\mathrm{k}_{\mathrm{app}}$, for the pristine and composite samples under UV and solar simulated (AM1.5G) radiation.

\begin{tabular}{lcccc}
\hline Sample & \multicolumn{3}{l}{ Dye degradation } & \multicolumn{2}{l}{ Rate constant $k a p p\left(\mathrm{~min}^{-1}\right)\left(\times 10^{-3}\right)$} \\
\hline & $\mathrm{UV}$ & $\mathrm{AM} 1.5 \mathrm{G}$ & $\mathrm{UV}$ & AM1.5G \\
\cline { 2 - 5 } $\mathrm{TiO}_{2}(\mathrm{P} 25)$ & 96 & 86 & $53.8 \pm 2.0$ & $8.16 \pm 0.17$ \\
$2.5 \mathrm{at} \% \mathrm{CeO}_{2} / \mathrm{TiO}_{2}$ & 52 & 29 & $11.7 \pm 0.6$ & $1.43 \pm 0.03$ \\
$5 \mathrm{at} \% \mathrm{CeO}_{2} / \mathrm{TiO}_{2}$ & 8 & 13 & $1.3 \pm 0.2$ & $0.62 \pm 0.04$ \\
$10 \mathrm{at} \% \mathrm{CeO}_{2} / \mathrm{TiO}_{2}$ & 5 & 9 & $0.9 \pm 0.1$ & $0.44 \pm 0.04$ \\
$\mathrm{CeO}_{2}$ & 3 & 30 & $0.5 \pm 0.1$ & $1.51 \pm 0.03$ \\
\hline
\end{tabular}

Cell cytotoxic and phototoxic assays were performed using the pristine $\mathrm{TiO}_{2}$ and $\mathrm{CeO}_{2}$ nanoparticle samples, as well as the 5 at $\% \mathrm{CeO}_{2} / \mathrm{TiO}_{2}$ as a result of the low photocatalytic activity and high $\mathrm{UV}$ attenuation it displayed, making the ideal sample for testing amongst the different $\mathrm{CeO}_{2}$ loaded samples prepared. The HaCaT cell line was chosen for both cytotoxic and phototoxic assays as it is composed of keratinocytes, the major cell type of the epidermis and the superficial layers of skin in most intimate contact with external contaminants ${ }^{61,62}$. Figure S5 highlights changes in the cell viability of the HaCaT cells when exposed to increasing concentrations of pristine $\mathrm{TiO}_{2}(\mathrm{P} 25), \mathrm{CeO}_{2}$, the 5 at $\% \mathrm{CeO}_{2} / \mathrm{TiO}_{2}$ nanocomposite and a known nanoparticulate toxicant, ZnO (Sigma Aldrich, size < $100 \mathrm{~nm}$ )63,64. Cell viability was reduced significantly after $24 \mathrm{~h}$ incubation in the presence of the tested $\mathrm{ZnO}$ nanoparticles at concentrations above $10 \mathrm{mg} \mathrm{L}^{-1}$. From the concentration-response curve obtained, the half maximal inhibitory concentration $\left(\mathrm{IC}_{50}\right)$ for $\mathrm{ZnO}$ nanoparticles tested was reached and calculated to be $16 \pm 1 \mathrm{mg}$ $\mathrm{L}^{-1}$. In contrast, cell viability was only partially reduced in the presence of $\mathrm{CeO}_{2}, \mathrm{TiO}_{2}(\mathrm{P} 25)$ or 5 at\% $\mathrm{CeO}_{2} / \mathrm{TiO}_{2}$ with cell viability significantly greater than that of cells incubated in the presence of corresponding cytotoxic concentrations of $\mathrm{ZnO}$. Unlike $\mathrm{ZnO}$ nanoparticles, for the pristine and nanocomposite samples the half maximal inhibitory concentration could not be reached and the final cell viabilities of $\mathrm{HaCaT}$ cells at the highest concentration tested $\left(300 \mathrm{mg} \mathrm{L}^{-1}\right)$ were only reduced to $87 \pm 5 \%, 79 \pm 9 \%$ and $70 \pm 10 \%$ for the $\mathrm{CeO}_{2}, 5$ at $\% \mathrm{CeO}_{2} / \mathrm{TiO}_{2}$ and $\mathrm{TiO}_{2}(\mathrm{P} 25)$ samples, respectively. 
The cell viability reduction observed across all tested concentrations did not vary substantially between samples, suggesting minimal differences in toxicity for the samples tested and a marginal influence of the $\mathrm{CeO}_{2}$ loading on the core $\mathrm{TiO}_{2}$ nanoparticle toxicity in absence of external $\mathrm{UV}$ radiation sources.

Figure 9 depicts the MTS assays performed with the HaCaT cell line and the pristine and nanocomposite samples under UV exposure for 5 and 15 min prior to the $24 \mathrm{~h}$ incubation period. Under both exposure periods, a significant reduction in viable cells relative to the control was observed in absence of the test samples. This is a consequence of the highly cytotoxic and genotoxic effects of UV radiation, which comprises of highly energetic wavelengths capable of inducing DNA lesions and elevating intracellular ROS levels, causing oxidative stress and leading to apoptosis ${ }^{65,66}$. For the 5 min UV exposure period (Fig. 9 a), the percentage of viable cells incubated with the test nanoparticle samples at 50 and $100 \mathrm{mg}$ $\mathrm{L}^{-1}$ did not vary significantly to the viability of the cells incubated in absence of test sample. This coincides with the relatively low toxicity observed from the MTS assays performed in absence of UV light at these concentrations (Fig. S5). However, each test sample at $100 \mathrm{mg} \mathrm{L}^{-1}$ caused a small but statistically significant increase in cell viability compared to cells exposed to UV light in the absence of each corresponding test material. This would suggest that, despite exposure to UV radiation for the allotted period, some protective effect was afforded by the tested samples. Indeed, as has been shown through UV-Vis absorption spectroscopy (Fig. 7), each of the tested samples, to a varying degree, display UV absorptive capabilities. However, with this screening and thus absorption of the incident UV by the samples tested, ROS generation was expected to occur, particularly for the $\mathrm{TiO}_{2}(\mathrm{P} 25)$ sample which was shown to have prominent photocatalytic properties (Fig. 8). One possible reason as to why this protective effect is more apparent than the potential toxicological effects of ROS production could be due to a lack of cellular internalization of the nanoparticles, leading to insubstantial cellular damage and impairment of metabolic activity. Another possibility is that, for the time period and intensity of UV emitted to the cells and the tested samples, the rate of ROS production was insufficient to induce a state of oxidative stress. Most animal cells contain natural enzymatic antioxidants to counteract ROS and other free radicals produced as by-products of metabolism or, such as in this work, ROS produced indirectly by UV radiation ${ }^{67,68}$. 
For the 15 min UV exposure period (Fig. 9 b), an overall decrease in cell viability is observed across all samples and concentrations as compared to the 5 min exposure period, simply as result of the higher dose of UV radiation impacting the cells. In contrast to the 5 min exposure period results (Fig. 9 a), a significant decrease in cell viability was observed when incubated with the $\mathrm{TiO}_{2}(\mathrm{P} 25)$ nanoparticles at a concentration of $100 \mathrm{mg} \mathrm{L}^{-1}$ compared to UV exposed cells incubated in the absence of test sample. In this instance, the rate of ROS production may be exceeding the rate at which these species can be scavenged by natural cellular processes, leading to a state of oxidative stress, metabolic impairment and potentially cell death. In addition, the screening effect afforded by the UV absorbing $\mathrm{TiO}_{2}(\mathrm{P} 25)$ nanoparticles is also outweighed by its potential free radical production, leading to cell damaging effects akin to the degradation of $\mathrm{CV}$ during the photodegradation experiments. In the case of the pristine $\mathrm{CeO}_{2}$ nanoparticles, cell viability was maintained at $25 \mathrm{mg} \mathrm{L}^{-1}$ whilst an increase in cell viability was observed for $\mathrm{CeO}_{2}$ nanoparticle concentrations at 50 and $100 \mathrm{mg} \mathrm{L}^{-1}$ compared to UV exposed cells incubated in the absence of test sample. As with the 5 min exposure period tests, the increase in cell viability at these higher test concentrations could be a result of the UV shielding afforded by the absorptive properties of the particles. Contributions from the free radical scavenging ability of the $\mathrm{CeO}_{2}$ nanoparticles could also be aiding in protecting the cells from photo-induced ROS and in minimizing oxidative damage ${ }^{68}$. A combination of both free radical scavenging and UV shielding by the $\mathrm{CeO}_{2}$ nanoparticles is likely the cause for the perceived increase in cell viability seen at these higher concentrations, as has been previously shown ${ }^{29}$. It can also be seen that the loading of $\mathrm{CeO}_{2}$ nanoparticles at the surface of $\mathrm{TiO} 2$ has an impact on the phototoxicity of the core material. Cell viability was maintained across all tested concentrations for the 5 at $\% \mathrm{CeO}_{2} / \mathrm{TiO}_{2}$ sample as compared to UV exposed cells incubated in the absence of test sample. The significant difference in cell viability between the pristine $\mathrm{TiO}_{2}(\mathrm{P} 25)$ nanoparticles and the nanocomposite sample, particularly at concentrations of 50 and $100 \mathrm{mg} \mathrm{L}^{-1}$, suggests that the application of $\mathrm{CeO}_{2}$ at this loading concentration is sufficient in mitigating the potentially phototoxic properties of the core $\mathrm{TiO}_{2}$. The reason for this could impart be due to a reduction in $\mathrm{TiO}_{2}$ surface active sites due to coverage by the $\mathrm{CeO}_{2}$ nanoparticles, as had been previously suggested 
in explaining its low photocatalytic activity towards the degradation of CV. It is also possible that the biocompatibility of $\mathrm{TiO}_{2}$ in the nanocomposite materials has been improved due to the low toxic and phototoxic effects exerted by the application of the $\mathrm{CeO}_{2}$ nanoparticles and the potential scavenging of photo-produced ROS, as demonstrated by the pristine $\mathrm{CeO}_{2}$ nanoparticles in this work.

\section{Conclusions}

Commercially used $\mathrm{TiO}_{2}$ nanoparticles in sunscreen products have the potential to generate free-radical species such as ROS when exposed to UV radiation. Such free radical species have been shown to cause oxidative damage to other active sunscreen ingredients, leading to a loss in protection, as well cause cytotoxic and genotoxic effects to human cell lines, particularly when exposed to UV radiation. Thus, modification of the photocatalytic activity of these particles whilst maintaining adequate UV attenuation is essential for their continued safe use in such products. The addition of free radical scavenging $\mathrm{CeO}_{2}$ nanodots through a simple precipitation method to the surface of highly photoactive commercial $\mathrm{TiO}_{2}$ nanoparticles was employed to demonstrate an alternative to classic silica and alumina based coatings. It was shown that an optimal $\mathrm{CeO}_{2}$ nanodot loading of 5 at $\%$ was required for drastically reducing the photocatalytic activity of the core $\mathrm{TiO}_{2}$ whilst also maintaining excellent $\mathrm{UV}$ absorptive properties. Furthermore, the phototoxic properties of the core commercial $\mathrm{TiO}_{2}$ nanoparticles towards $\mathrm{HaCaT}$ cells were shown to be diminished in the nanocomposite sample due to the potential biomimetic antioxidant behaviour of $\mathrm{CeO}_{2}$. Thus, we have demonstrated the potential for $\mathrm{CeO}_{2}$ nanodots as an additive to commercial sunscreen active $\mathrm{TiO}_{2}$ that can help improve biocompatibility, provide UV protection and minimize formulation degradation. The facile preparation of the nanocomposite material also demonstrates wider-applicability to the preparation of various oxide nanocomposite systems. Further study and application of this synthesis approach, enabling some degree of control over ROS generation by photocatalytic materials, may lead to future advances light-driven catalytic applications.

\section{Conflicts of interest}

There are no conflicts to declare.

\section{Acknowledgements}


This research has been conducted with the support of the Australian Government Research Training Program Scholarship and is part of the University of Wollongong Global Challenges project "NEXT GENERATION SUNSCREENS: Designed and tested for Australian conditions, with global implications for sun safety". This research used equipment funded by the Australian Research Council (ARC) Linkage, Infrastructure, Equipment, Facilities (LIEF) grant (LE120100104) located at the UOW Electron Microscopy Centre, and the authors would like to acknowledge Dr. Gilberto Casillas-Garcia for his assistance in using this equipment. The authors also acknowledge the use of facilities within the Australian National Fabrication Facilities Materials Node and Dr. J. Guy Lyons from the University of Sydney for supplying the cell line used in this work.

\section{References}

1 D. Dondi, A. Albini and N. Serpone, Photochem. Photobiol. Sci, 2006, 5, 835-843.

2 R. M. Lucas, M. Norval, R. E. Neale, A. R. Young, F. R. de Gruijl, Y. Takizawa and J. C. van der Leun, Photochem. Photobiol. Sci, 2015, 14, 53-87.

3 F. R. de Gruijl, J. Longstreth, M. Norval, A. P. Cullen, H. Slaper, M. L. Kripke, Y. Takizawa and J. C. van der Leun, Photochem. Photobiol. Sci, 2003, 2, 16-28.

4 N. Serpone, D. Dondi and A. Albini, Inorg. Chim. Acta, 2007, 360, 794-802.

5 N. Roy, N. Suzuki, C. Terashima, A. Fujishima, Bull. Chem. Soc. Jpn, 2019, 92, 178-192.

6 D. M. Tobaldi, R. A. S. Ferreira, R. C. Pullar, M. P. Seabra, L. D. Carlos and J. A. Labrincha, J. Mater. Chem. C, 2015, 3, 4970-4986.

7 K. Bogusz, M. Tehei, M. Lerch, S. X. Dou, H. K. Liu and K. Konstantinov, J. Mater. Chem. C, $2018,6,5639-5650$.

8 G. P. Dransfield, Radiat. Prot. Dosim., 2000, 91, 271-273. 
9 K. Schilling, B. Bradford, D. Castelli, E. Dufour, J. F. Nash, W. Pape, S. Schulte, I. Tooley, J. van den Bosch and F. Schellauf, Photochem. Photobiol. Sci, 2010, 9, 495-509.

10 J. Schulz, H. Hohenberg, F. Pflücker, E. Gärtner, T. Will, S. Pfeiffer, R. Wepf, V. Wendel, H. Gers-Barlag and K. P. Wittern, Adv. Drug Del. Rev., 2002, 54, S157-S163.

11 J. Lekki, Z. Stachura, W. Dąbroś, J. Stachura, F. Menzel, T. Reinert, T. Butz, J. Pallon, E. Gontier, M. D. Ynsa, P. Moretto, Z. Kertesz, Z. Szikszai and A. Z. Kiss, Nuclear Instruments and Methods in Physics Research Section B: Beam Interactions with Materials and Atoms, 2007, 260, 174177.

12 T. Pinheiro, J. Pallon, L. C. Alves, A. Veríssimo, P. Filipe, J. N. Silva and R. Silva, Nuclear Instruments and Methods in Physics Research Section B: Beam Interactions with Materials and Atoms, 2007, 260, 119-123.

13 J.-J. Yin, J. Liu, M. Ehrenshaft, J. E. Roberts, P. P. Fu, R. P. Mason and B. Zhao, Toxicol. Appl. Pharmacol., 2012, 263, 81-88.

14 C.-C. Wang, S. Wang, Q. Xia, W. He, J.-J. Yin, P. P. Fu and J.-H. Li, Journal of Nanoscience and Nanotechnology, 2013, 13, 3880-3888.

15 Y. Ren, X. Liu, R. Geng, Q. Lu, R. Rao, X. Tan, X. Yang and W. Liu, Nanomaterials, 2018, 8, 253.

16 Y. Ji, L. Zhou, C. Ferronato, A. Salvador, X. Yang and J.-M. Chovelon, Applied Catalysis B: Environmental, 2013, 140-141, 457-467.

17 B. O'Regan and M. Grätzel, Nature, 1991, 353, 737.

18 J. Li and N. Wu, Catalysis Science \& Technology, 2015, 5, 1360-1384.

19 Z. Wang, C. Li, K. Domen, Chemical Society Reviews, 2019, 48, 2109-2125.

20 J. A. Klein and S. L. Ackerman, The Journal of Clinical Investigation, 2003, 111, 785-793. 
21 D. I. Feig, L. C. Sowers and L. A. Loeb, Proceedings of the National Academy of Sciences, 1994, 91, 6609-6613.

22 A. M. El-Toni, S. Yin and T. Sato, J. Colloid Interface Sci., 2006, 300, 123-130.

23 T. Furusawa, K. Honda, E. Ukaji, M. Sato and N. Suzuki, Mater. Res. Bull., 2008, 43, 946-957.

24 I. A. Siddiquey, T. Furusawa, M. Sato, K. Honda and N. Suzuki, Dyes and Pigments, 2008, 76, 754-759.

25 Y. Bai, Z. Li, B. Cheng, M. Zhang and K. Su, RSC Adv., 2017, 7, 21758-21767.

26 S. M. Solaiman, J. Algie, S. Bakand, R. Sluyter, V. Sencadas, M. Lerch, X.-F. Huang, K. Konstantinov and P. J. Barker, Crit. Rev. Toxicol., 2019, DOI: 10.1080/10408444.2019.1579780, 1-18.

27 S. A. Ansari, M. M. Khan, M. O. Ansari, S. Kalathil, J. Lee and M. H. Cho, RSC Adv., 2014, 4, 16782-16791.

28 F. Caputo, M. De Nicola, A. Sienkiewicz, A. Giovanetti, I. Bejarano, S. Licoccia, E. Traversa and L. Ghibelli, Nanoscale, 2015, 7, 15643-15656.

29 T. Pirmohamed, J. M. Dowding, S. Singh, B. Wasserman, E. Heckert, A. S. Karakoti, J. E. S. King, S. Seal and W. T. Self, Chem. Commun., 2010, 46, 2736-2738.

30 L. T. N. Ngoc, V. K. H. Bui, J.-Y. Moon and Y.-C. Lee, Journal of Nanoscience and Nanotechnology, 2019, 19, 6369-6375.

31 F. Caputo, A. Giovanetti, F. Corsi, V. Maresca, S. Briganti, S. Licoccia, E. Traversa and L. Ghibelli, Front. Pharmacol., 2018, 9.

32 F. Pagliari, C. Mandoli, G. Forte, E. Magnani, S. Pagliari, G. Nardone, S. Licoccia, M. Minieri, P. Di Nardo and E. Traversa, ACS Nano, 2012, 6, 3767-3775.

33 Y. Li, X. Hou, C. Yang, Y. Pang, X. Li, G. Jiang and Y. Liu, Sci. Rep., 2019, 9, 2595.

34 Y. Zhang, G. Zhao, Y. Zhang and X. Huang, Green Chem., 2014, 16, 3860-3869. 
36 B. Yuan, Y. Long, L. Wu, K. Liang, H. Wen, S. Luo, H. Huo, H. Yang and J. Ma, Catalysis Science \& Technology, 2016, 6, 6396-6405.

37 B. Huang, D. Yu, Z. Sheng and L. Yang, J. Environ. Sci, 2017, 55, 129-136.

38 C. Karunakaran and P. Gomathisankar, ACS Sustainable Chemistry \& Engineering, 2013, 1, $1555-1563$.

39 J. Jiao, Y. Wei, Z. Zhao, J. Liu, J. Li, A. Duan and G. Jiang, Ind. Eng. Chem. Res., 2014, 53, $17345-17354$.

40 D. Cardillo, M. Weiss, M. Tehei, T. Devers, A. Rosenfeld and K. Konstantinov, RSC Adv., 2016, 6, 65397-65402.

41 P. Boukamp, R. T. Petrussevska, D. Breitkreutz, J. Hornung, A. Markham and N. E. Fusenig, J. Cell Biol., 1988, 106, 761-771.

42 A. Morlando, V. Sencadas, D. Cardillo and K. Konstantinov, Powder Technol., 2018, 329, 252259.

43 P. M. Shafi and A. C. Bose, AIP Advances, 2015, 5, 057137.

44 I. Singh and B. Birajdar, RSC Adv., 2017, 7, 54053-54062.

45 X. Qin, L. Jing, G. Tian, Y. Qu and Y. Feng, J. Hazard. Mater., 2009, 172, 1168-1174.

46 B. Erdem, R. A. Hunsicker, G. W. Simmons, E. D. Sudol, V. L. Dimonie and M. S. El-Aasser, Langmuir, 2001, 17, 2664-2669.

47 J. Y. Ying and A. Tschöpe, The Chemical Engineering Journal and the Biochemical Engineering Journal, 1996, 64, 225-237.

48 J. Xu, J. Harmer, G. Li, T. Chapman, P. Collier, S. Longworth and S. C. Tsang, Chem. Commun., 2010, 46, 1887-1889. 

papers of the American Chemical Society, 2017, 254.

50 B. C. Nelson, M. E. Johnson, M. L. Walker, K. R. Riley and C. M. Sims, Antioxidants, 2016, 5,15 .

51 P. Eriksson, A. A. Tal, A. Skallberg, C. Brommesson, Z. Hu, R. D. Boyd, W. Olovsson, N. Fairley, I. A. Abrikosov, X. Zhang and K. Uvdal, Sci. Rep., 2018, 8, 6999.

52 Y. Xue, Q. Luan, D. Yang, X. Yao and K. Zhou, J. Phys. Chem. C, 2011, 115, 4433-4438.

53 A. Naldoni, M. Allieta, S. Santangelo, M. Marelli, F. Fabbri, S. Cappelli, C. L. Bianchi, R. Psaro and V. Dal Santo, J. Am. Chem. Soc., 2012, 134, 7600-7603.

54 I. K. Konstantinou and T. A. Albanis, Applied Catalysis B: Environmental, 2004, 49, 1-14.

55 A. Houas, H. Lachheb, M. Ksibi, E. Elaloui, C. Guillard and J.-M. Herrmann, Applied Catalysis B: Environmental, 2001, 31, 145-157.

56 K. Tanaka, K. Padermpole and T. Hisanaga, Water Res., 2000, 34, 327-333.

57 J. Schneider, M. Matsuoka, M. Takeuchi, J. Zhang, Y. Horiuchi, M. Anpo and D. W. Bahnemann, Chem. Rev., 2014, 114, 9919-9986.

58 S. Cong and Y. Xu, J. Phys. Chem. C, 2011, 115, 21161-21168.

59 M. Fronzi, A. Soon, B. Delley, E. Traversa and C. Stampfl, The Journal of Chemical Physics, 2009, 131, 104701.

60 T. Ghoshal, P. G. Fleming, J. D. Holmes and M. A. Morris, J. Mater. Chem., 2012, 22, 2294922957.

61 F. Rancan, B. Nazemi, S. Rautenberg, M. Ryll, S. Hadam, Q. Gao, S. Hackbarth, S. F. Haag, C. Graf, E. Rühl, U. Blume-Peytavi, J. Lademann, A. Vogt and M. C. Meinke, Skin Res. Technol., 2013, 20, 182-193. 
Sciences, 2012, 4, 14-18.

63 S. S, V. K, P. S, R. N and K. K, Toxicology Reports, 2017, 4, 427-430.

64 J. Cadet, E. Sage and T. Douki, Mutation Research/Fundamental and Molecular Mechanisms of Mutagenesis, 2005, 571, 3-17.

65 U. Panich, G. Sittithumcharee, N. Rathviboon and S. Jirawatnotai, Stem Cells Int., 2016, 2016.

66 J. J. Yohn, D. A. Norris, D. G. Yrastorza, I. J. Buno, J. A. Leff, S. S. Hake and J. E. Repine, J. Invest. Dermatol., 1991, 97, 405-409.

67 E. Birben, U. M. Sahiner, C. Sackesen, S. Erzurum and O. Kalayci, World Allergy Organization Journal, 2012, 5, 9.

68 I. Celardo, M. De Nicola, C. Mandoli, J. Z. Pedersen, E. Traversa and L. Ghibelli, ACS Nano, $2011,5,4537-4549$.

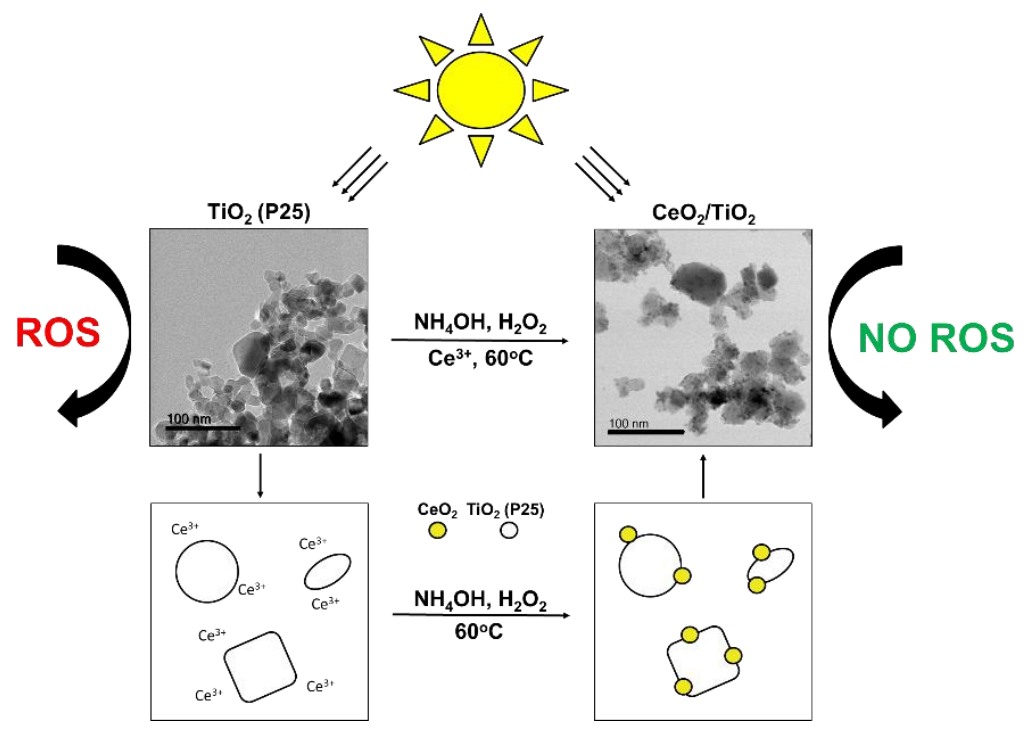

Figure 1: Synthesis scheme for preparation of the conceptualized low photocatalytic $\mathrm{CeO}_{2} / \mathrm{TiO}_{2}$ nanocomposite particles. 


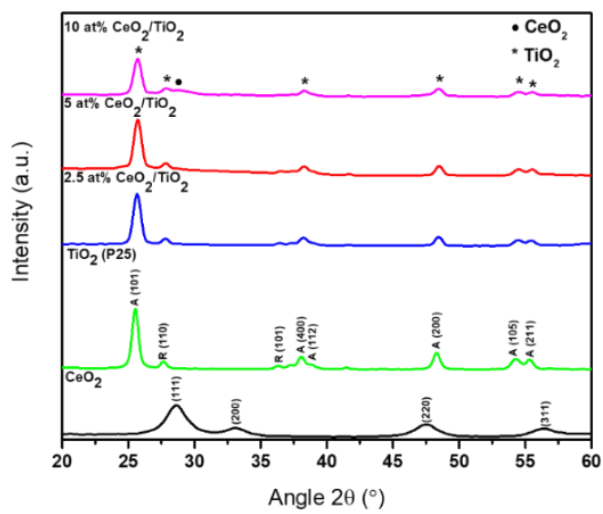

Figure 2: XRD patterns for the as-prepared nanocomposites as well as for pristine $\mathrm{TiO}_{2}$ (P25) and $\mathrm{CeO}_{2}$. Peaks indexed for the $\mathrm{TiO}_{2}$ and $\mathrm{CeO}_{2}$ containing samples according to the following PDF cards: Anatase (03-065-5714), Rutile (03-065-1119), $\mathrm{CeO}_{2}$ (01-0898436). 
Ti $2 p$

a)

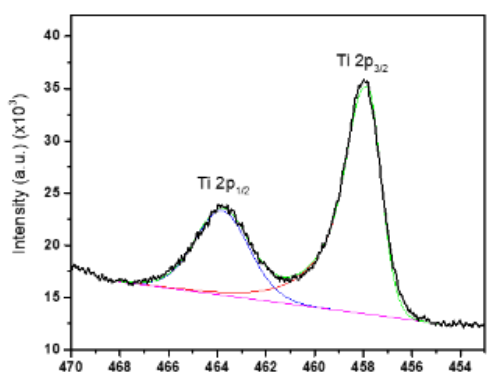

b)

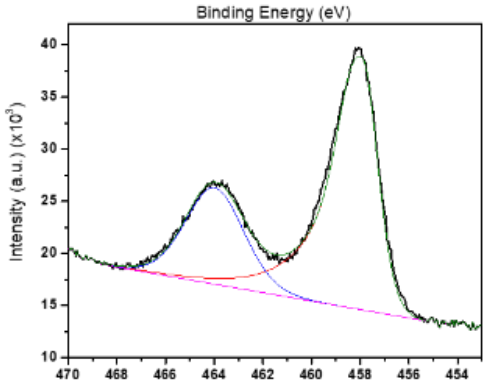

c)

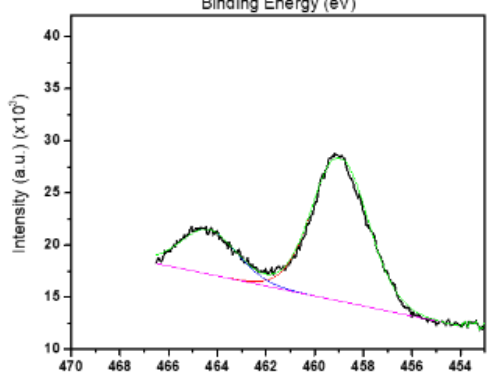

d)

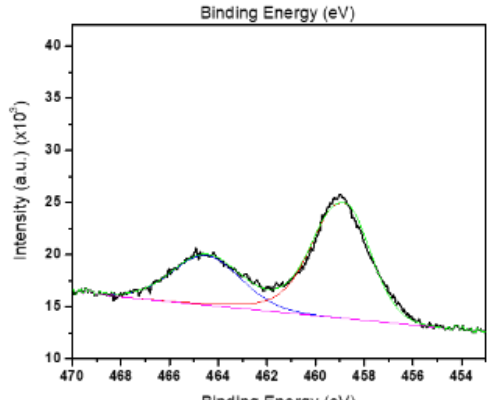

e)

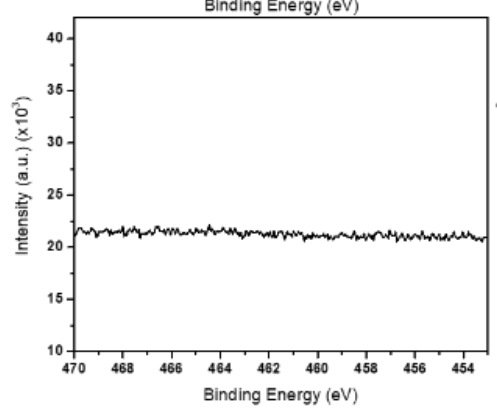

Ce 3d
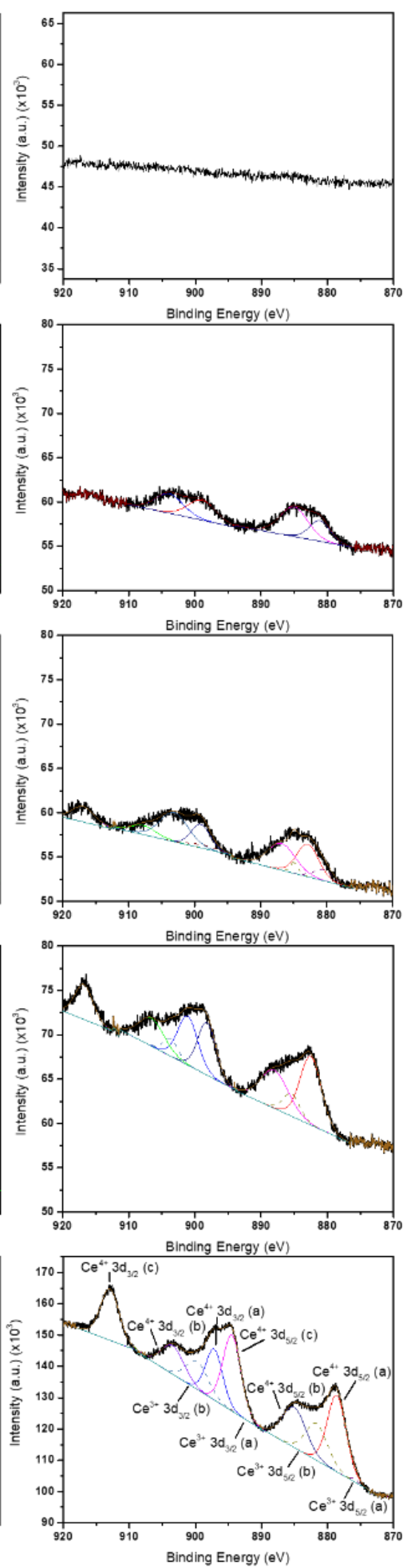

Figure 3: Narrow XPS spectra and fitted peaks of the Ti $2 p$ (left column) and Ce $3 d$ (right column) regions for the a) pristine $\mathrm{TiO}_{2}(\mathrm{P} 25)$, b) 2.5 at\%, c) 5 at\%, d) 10 at\% $\mathrm{CeO}_{2} / \mathrm{TiO}_{2}$ nanocomposites and e) pristine $\mathrm{CeO}_{2}$. Each spectra includes lines for the raw data, fitted peaks and envelope for each peak fit (excluding spectra where no peaks were observed). 


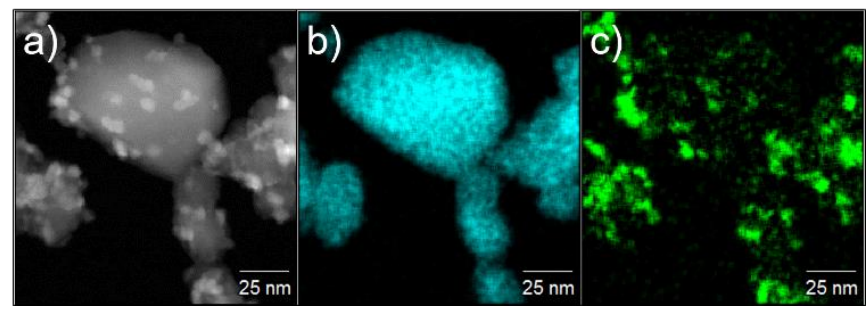

Figure 4: TEM micrographs and EDS mapped images of the 10 at\% nanocomposite $\mathrm{CeO}_{2} / \mathrm{TiO}_{2}$ sample where a) corresponds to the base dark field image, $b$ ) the $\mathrm{Ti}$ content and c) the Ce content.

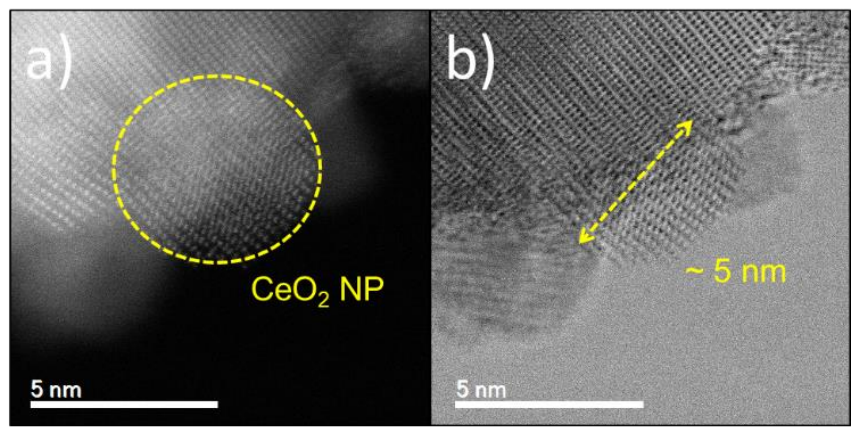

c)

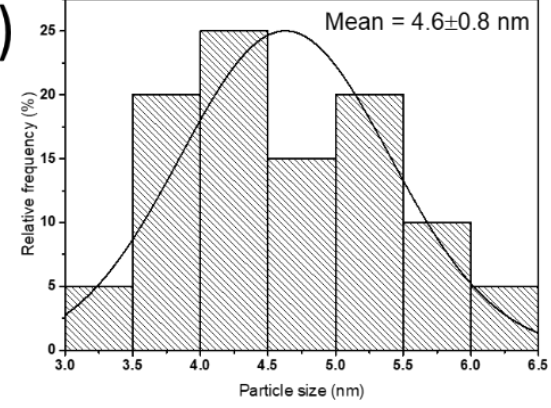

Figure 5: HRTEM images of the 10 at $\% \mathrm{CeO}_{2} / \mathrm{TiO}_{2}$ nanocomposite sample obtained in a) dark field and $b$ ) bright field imaging modes. c) Particle size distribution of the $\mathrm{CeO}_{2}$ nanoparticles present on the surface of $\mathrm{TiO}_{2}$ nanoparticles in the 10 at\% nanocomposite sample. 


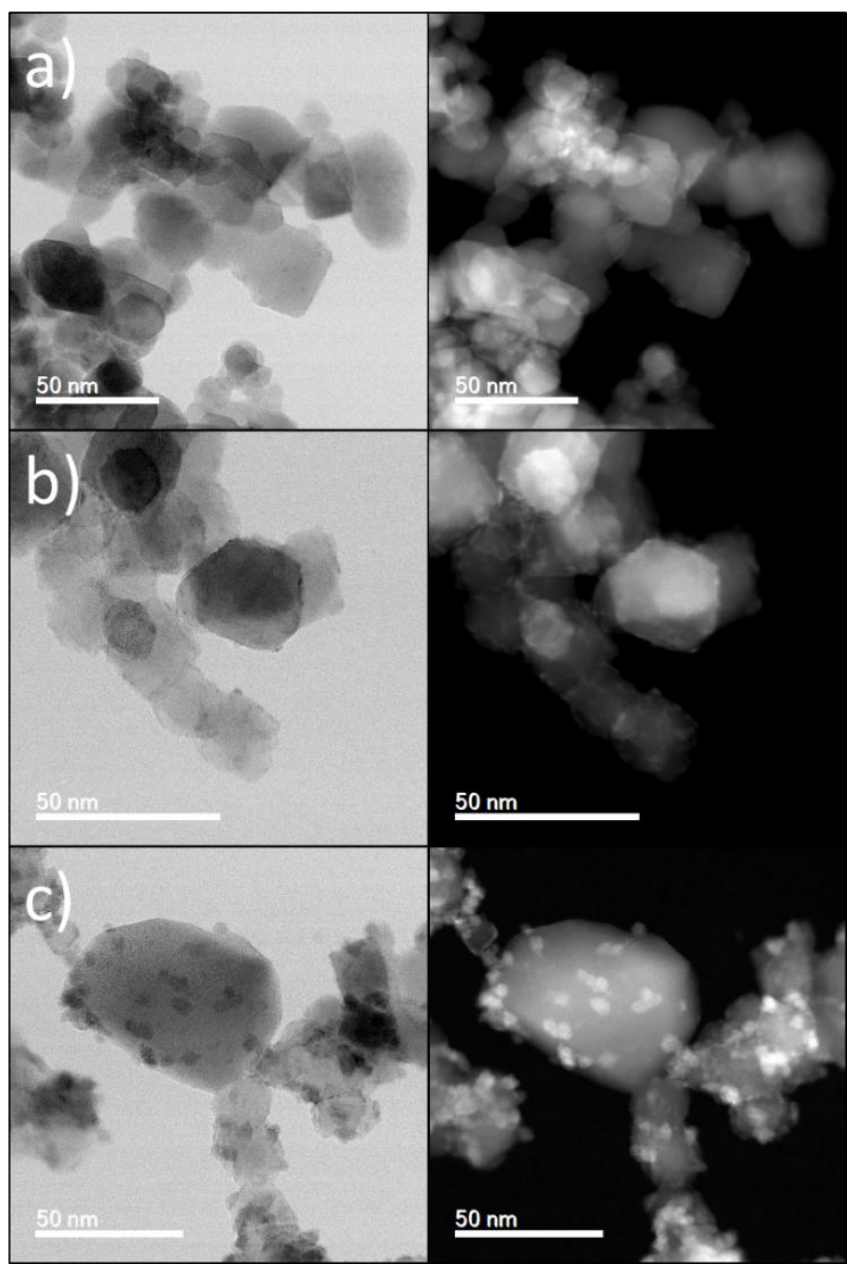

Figure 6: Bright field and corresponding dark field images of the a) 2.5 at\%, b) 5 at\% and c) 10 at\% $\mathrm{CeO}_{2} / \mathrm{TiO}_{2}$ nanocomposite samples.

a)

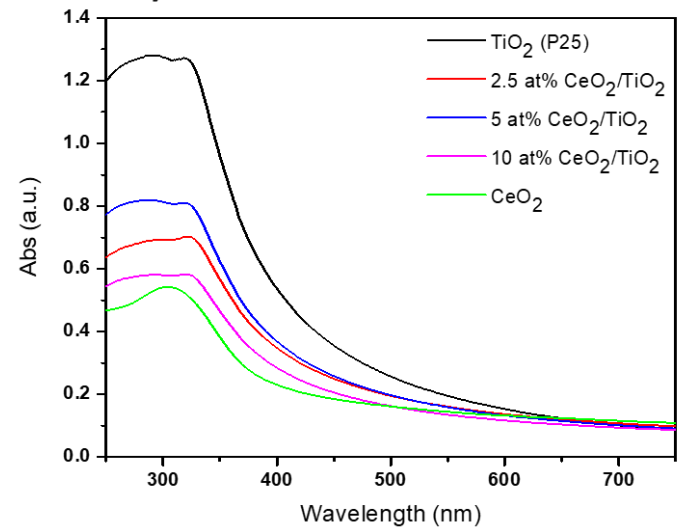

b)

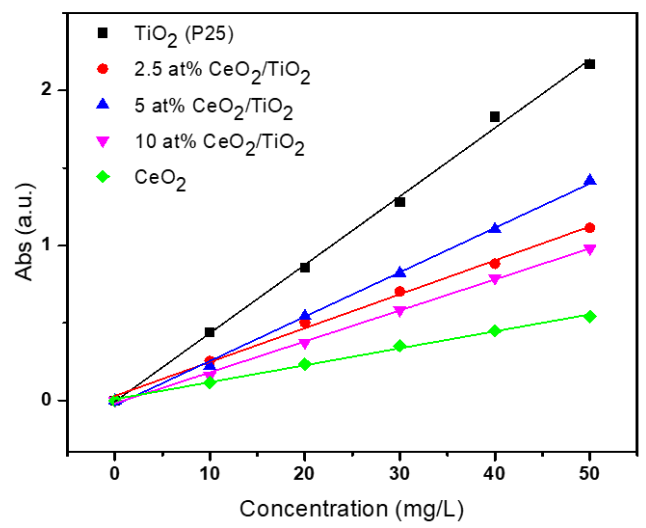

Figure 7: a) UV-Vis absorption spectra recorded for the $\mathrm{CeO} 2 / \mathrm{TiO} 2$ nanocomposites, as well as pristine $\mathrm{TiO} 2$ (P25) and $\mathrm{CeO} 2$ nanoparticles for $30 \mathrm{mg} \mathrm{L}-1$ suspensions prepared in ethanol. b) Corresponding Beer-Lambert plots used to calculate extinction coefficient values. 

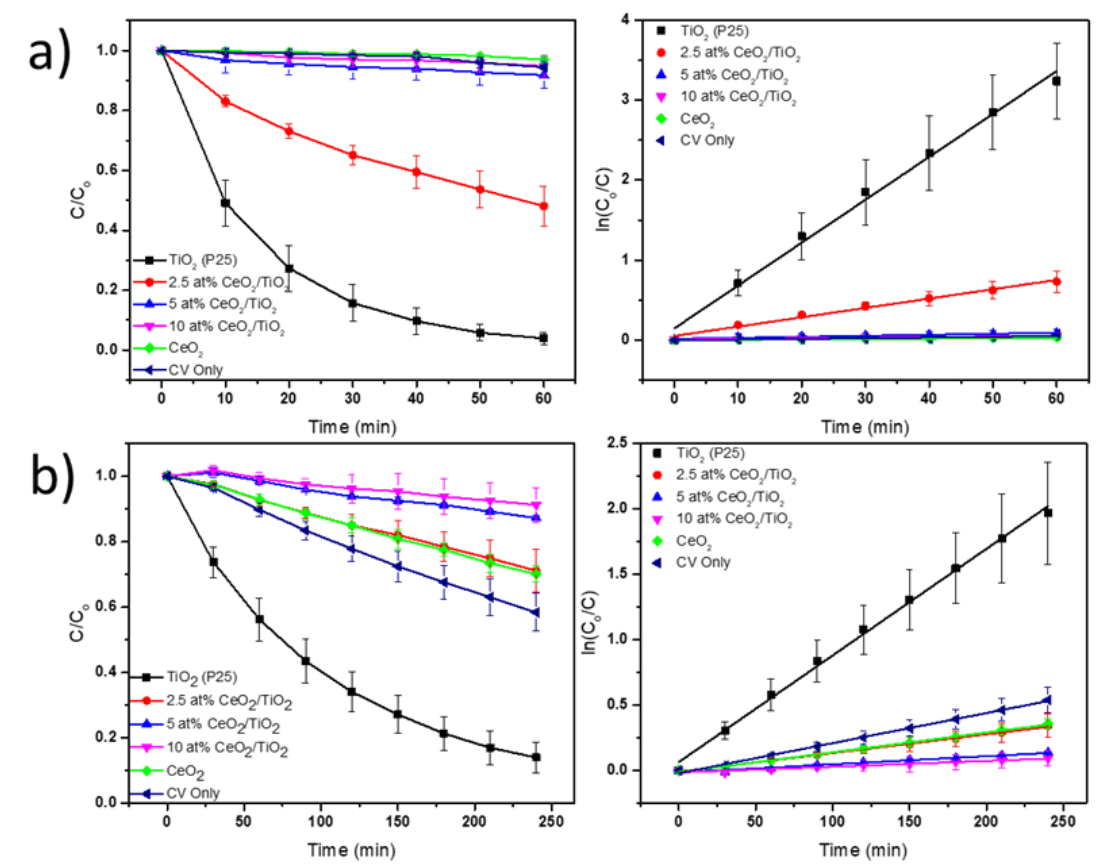

Figure 9: Photoactivity assessment of the tested samples, highlighting the relative absorbance behaviour of the crystal violet dye and the degradation kinetics when exposed to a) UV radiation and b) solar simulated radiation. Data represents the mean \pm SEM ( $n=3$ experiments).

a) $5 \mathrm{~min}$

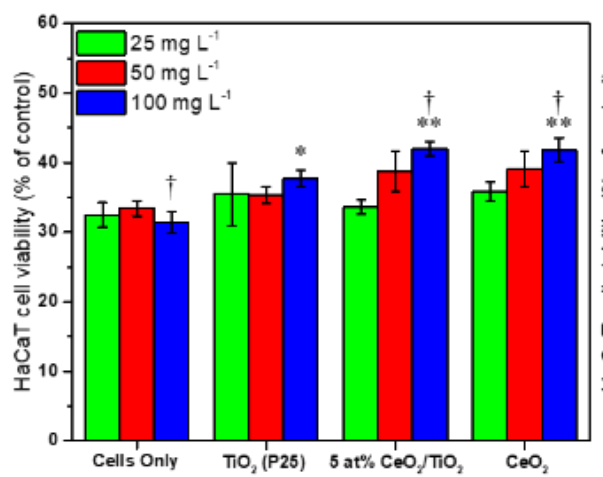

b) $15 \mathrm{~min}$

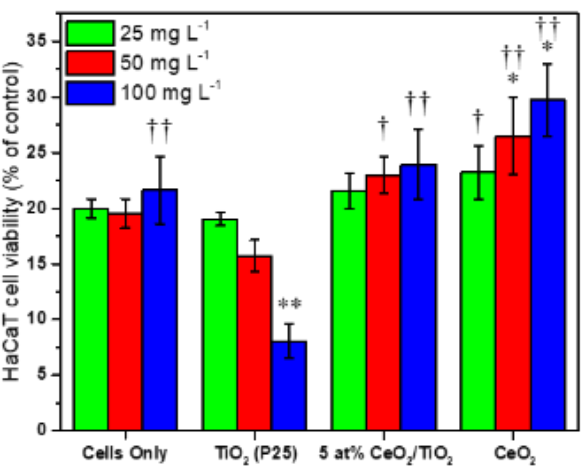

Figure 8: HaCaT cell viability after $24 \mathrm{~h}$ incubation with TiO2 (P25), 5 at\% $\mathrm{CeO} 2 / \mathrm{TiO} 2$ and $\mathrm{CeO} 2$ when exposed to UV radiation prior for a) $5 \mathrm{~min}$ and b) $15 \mathrm{~min}$ at an intensity of $6 \mathrm{~mW} \mathrm{~cm}-2$. HaCaT cell viability (\% of control) refers to the normalized absorbance readings for all nanoparticle, nanocomposite and cell only wells exposed to UV irradiation relative to a control plate in absence of UV exposure for each concentration tested. Data represents mean \pm SEM ( $n=3$ experiments). One-way ANOVA and Tukey post-hoc tests were performed to assess statistically different data sets. ${ }^{*}$ and ${ }^{* *}$ refer to $p<0.05$ and $p<0.01$ when compared to the Cell Only data sets for the corresponding concentrations. $\uparrow$ and $\uparrow \dagger$ refer to $p<0.05$ and $p<0.01$ when compared to the $\mathrm{TiO}_{2}$ (P25) data sets for the corresponding concentrations. 


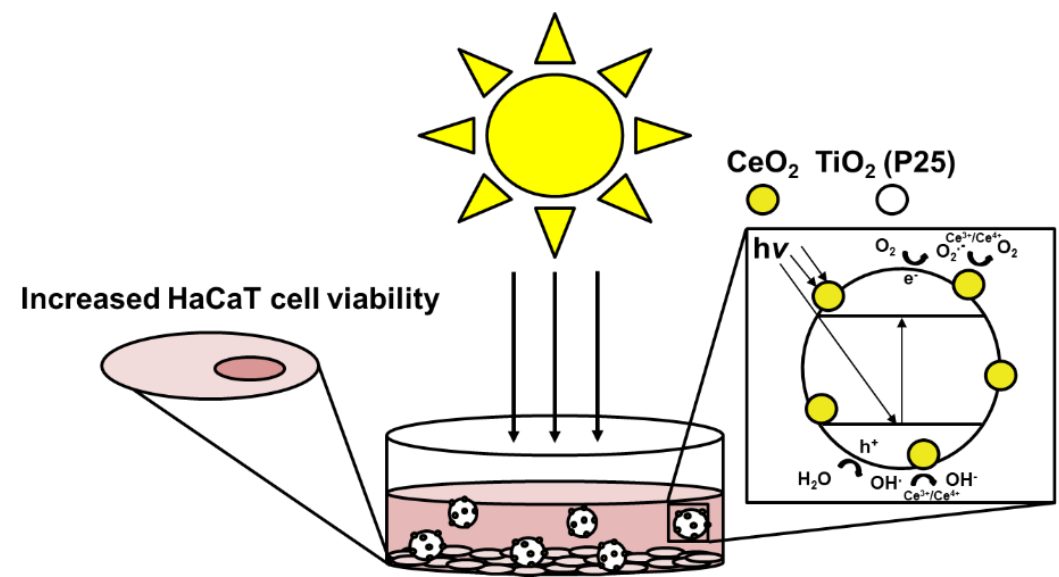

Figure 10: Possible mechanistic scheme for the improved HaCaT cell viability observed after UV radiation exposure when in the presence of the $\mathrm{CeO}_{2} / \mathrm{TiO}_{2}$ nanocomposite particles, detailing UV light blocking and $\mathrm{ROS}$ scavenging by the surface bound $\mathrm{CeO}_{2}$ nanoparticles. 